\title{
Breaking Free of Chevron's Constraints: Zuni Public School District No. 89 v. U.S. Department of Education
}

\author{
Osamudia R. James ${ }^{*}$
}

I. INTRODUCTION

"It is easy to forget that important Supreme Court cases involve people; it is even easier to forget they are rooted in particular places." In Zuni Public School District No. 89 v. U.S. Department of Education, ${ }^{2}$ the Supreme Court applied Chevron review to a school finance case. Even as the Court heard oral argument in the case, all parties forgot that the case's outcome would have a profound impact on the people and places involved. The people are Native American schoolchildren in the state of New Mexico. The places are two public school districts, Zuni Public School District, and Gallup-McKinley Public School District, both located in the Northwest quadrant of the state.

Zuni and Gallup-McKinley are both located on or near tax-exempt American Indian reservations. As such, the districts are eligible to receive Impact Aid - federal funding meant to ensure that school districts are not penalized for their inability to raise revenue for education through property taxes. $^{3}$ If, however, the Department of Education determines that a state's school finance system equally distributes resources to all students, the state may offset state funding to impacted districts by the

\footnotetext{
Copyright (C) 2007 by Osamudia R. James. William H. Hastie Fellow, University of Wisconsin Law School; B.A., University of Pennsylvania, 2001; J.D., Georgetown University Law Center, 2004. I am grateful to Stephanie Tai and John Ohnesorge for their feedback on earlier drafts of this article, and to William Clune for his guidance through the often complex maze of school finance equity. Finally, I would like to thank my husband, Kamal James, who has never failed to support me in all my endeavors, professional or personal.

1. Richard Schragger, San Antonio v. Rodriguez and the Legal Geography of School Finance Reform 1, (University of Virginia Public LaW and Legal Theory Working PaPer Series, Working Paper No. 64, 2007), available at http://law.bepress.com/uvalwps/uva_publiclaw/art64.

2. 127 S. Ct. 1534 (2007).

3. Id. at 1538 .
} 
amount each district receives in Impact Aid. ${ }^{4}$ Such was the case for the Zuni and Gallup-McKinley school districts.

Zuni and Gallup-McKinley challenged the Secretary of Education's use of a formula to determine that New Mexico was equalized. The statutory interpretation that led to the Secretary's choice of formula was subject to Chevron review. ${ }^{5}$ An integral element of Chevron review is to ensure that the Secretary's interpretation, and its effects, are permissible in light of congressional intent. ${ }^{6}$ The Court's compulsion, however, to decide "who gets to decide" under Chevron review eclipsed any analysis of the consequences of the Secretary's interpretation and formula choice. As a result, the two districts are now forced to choose between school buildings with running water and hiring experienced teachers able to address the unique learning needs of their Native American students. Although this is the kind of penalty Congress sought to avoid through Impact Aid, the Court ignored the problem altogether. The Court's application of Chevron review in Zuni was too constraining, and produced an outcome misaligned with congressional intent.

Part II provides the historical context for the case, including a discussion of the challenges inherent in efforts to equalize financial resources in education, New Mexico's efforts to equalize funding within the state, and the federal government's role in ensuring school finance equity through the Impact Aid program. Part II also briefly summarizes the procedural history of the case. Parts III and IV explain Chevron review and how the Court applied Chevron review to the case. Part V analyzes both the constraining nature of Chevron review in the case, and the failure of Chevron review to assist the Court in determining whether agency interpretation was permissible in light of congressional intent and agency expertise. Part V also resurrects calls for replacement of Chevron step two with arbitrary and capricious "hard-look" review. This change would have ensured that the Court considered relevant policy implications and the practical consequences of the Department's interpretation when determining whether to extend deference to the Secretary's decision which had such significant adverse consequences for Native American schoolchildren in New Mexico.

4. Id.

5. Id. at $1540-41$.

6. See id. at 1541 (summarizing congressional intent and legislative history). 


\section{HISTORICAL BACKGROUND}

\section{A. School Finance Equity}

The dispute about the equity of New Mexico's school finance system and the appropriateness of the Secretary's equalization formula is a recent development in the long history of battles regarding education and school finance equity. ${ }^{7}$ Although the details of school finance systems vary from state to state, most states generally delegate responsibility for raising revenue to individual districts. ${ }^{8}$ A district's ability to raise revenue for its schools is usually determined by the wealth of its tax base. Thus, disparities in property wealth yield disparities in educational funding. The role of the state is typically as a partner, ensuring minimum education needs are met.

States essentially guarantee inequalities in funding by allowing districts to raise revenue locally for education, particularly when a state has not adopted an equalization program. As such, some school districts become "enclaves of affluence," while other districts are left with minimal fiscal strength. ${ }^{9} \quad$ These enclaves have become adept at convincing legislatures that their advantage is justified, leading some scholars to note that the public school system in the United States is not public, but rather "quasi-public" or "quasi-private."10 In this quasipublic system, the interests of wealthier districts are insulated, geographically defined, and protected by state legislatures that refuse to enact school funding programs to equalize resources. ${ }^{11}$ State court challenges to education financing systems that perpetuate these inequalities proliferated in the aftermath of San Antonio Independent School District v. Rodriguez, ${ }^{12}$ where the Court held that disparities caused by school systems that relied on property taxes were not violations of the United States Constitution because education is not a fundamental right. ${ }^{13}$ At the heart of these challenges is concern for the

7. See Julie K. Underwood, School Finance Adequacy as Vertical Equity, 28 U. MiCH. J.L. REFORM 493, 497-502 (1995) (outlining the three waves of school finance litigation at the state and federal levels).

8. See Kern Alexander \& Richard G. Salmon, Public School Finance 18 (1995) (discussing educational taxation at the state and local level).

9. Id. at $146-47$.

10. Id. at $147-48$.

11. Id.

12. 411 U.S. 1 (1973).

13. Id. at 4-6. "Lawsuits challenging state methods of funding public schools have been brought in 45 of the 50 states." National Access Network Webpage, http://www.schoolfunding .info/litigation/lititgation.php3 (last visited Aug. 12, 2007). 
ways in which education finance resources are distributed, and the relationship between spending and student achievement.

Several equity principles can be utilized when assessing the distribution of resources, including horizontal equity, vertical equity, and adequacy. Horizontal equity provides that students who are alike should be treated alike, and requires that all students receive equal shares of local and state revenue per pupil. ${ }^{14}$ Several statistics assess the level of horizontal equity within a state, including the federal range ratio. ${ }^{15}$ The federal range ratio, also referred to as a restricted range ratio, is the formula included in the text of the Impact Aid statute. ${ }^{16}$

Vertical equity accounts for the reality that some students need or deserve more services than others, and that providing more services requires more funding. ${ }^{17}$ Accordingly, achieving vertical equity requires identifying characteristics that can be used as a basis for distributing additional resources to certain students, or the programs and school districts that educate those students. ${ }^{18}$ Student characteristics that justify additional funding include physical or mental disabilities, educational disadvantages stemming from a low-income background, or limited English proficiency. ${ }^{19}$ District characteristics that justify additional funding might include, for example, unique transportation costs associated with very large, or very small, districts. ${ }^{20}$ School program characteristics, such as vocational programs or magnet schools, may also warrant additional resources. ${ }^{21}$

Finally, adequacy is defined as "the provision of a set of strategies, programs, curriculum, and instruction, with appropriate adjustments for special-needs students, districts, and schools, and their full financing, that is sufficient to teach students to high standards." ${ }^{, 2}$ To the extent that adequacy addresses how much is required to educate students based on each student's individual need, adequacy can be partially addressed

14. Allan R. Odden \& Lawrence O. Picus, School Finance: A Policy Perspective 60 (2000).

15. AlEXANDER \& SALMON, supra note 8, at 234-39.

16. See id. at 235-36 (explaining that the federal range ratio used by the federal government in the Impact Aid program is mathematically equivalent to the restricted range ratio).

17. ODDEN \& PICUS, supra note 14, at 66-67.

18. Id.

19. Id. See also William H. Clune, Accelerated Education as a Remedy for High Poverty Schools, 28 U. MICH. J.L. REFORM 655, 667-69 (1995) (advocating for the provision of additional funds for accelerated instruction in high-poverty schools).

20. ODDEN \& PICUS, supra note 14, at 67.

21. Id.

22. Id. at 69 . 
through a combination of horizontal and vertical equity. ${ }^{23}$ At the same time, adequacy also addresses the relationship between educational inputs and educational outputs. Educational inputs include "programs, curriculum, and instruction that are sufficient to teach students to high standards," while outputs include "the measurement of the achievement that results." ${ }^{24}$ Considering the link between equity and adequacy is integral to ensuring equal educational opportunities for all students. ${ }^{25}$

The concept of adequacy, however, has not been without debate. Some have argued that there is no consistent relationship between money input and achievement output, and that to obtain more money for education is simply "throwing good money after bad."26 This "production-function" ${ }^{, 27}$ critique of school finance has its origins in the Coleman report, ${ }^{28}$ which was interpreted as indicating that schools have little influence on student achievement independent of family background and social context. ${ }^{29}$ The production-function model, however, has been criticized as inadequate when applied to the education system. ${ }^{30}$ Moreover, methodological flaws in the research underlying the Coleman report have rendered the report's conclusions a result of flawed

23. The two concepts of adequacy and equity are often considered interchangeable, particularly in school finance reform litigation where remedies can be justified based on either concept. See Underwood, supra note 7, at 513-19 (equating adequacy and vertical equity). But see William H. Clune, The Shift from Equity to Adequacy in School Finance, 8 EDUC. POL'Y 376, 376-77 (1994) (describing the shift away from an equity model to an adequacy model, where the emphasis is no longer merely on inputs, but on high minimum educational outcomes).

24. ODDEN \& PICUS, supra note 14, at 69. See also Clune, supra note 19, at 665-80 (arguing that adequacy responds to the needs of high-poverty schools by setting "appropriate, high expectations of performance, and ... deliver[ing] the resources and governance necessary to reach those goals").

25. See generally NATIONAL RESEARCH COUNCIL, EQUiTy AND ADEQUACY IN EdUCATION FinANCE (Helen F. Ladd et al. eds., 1999).

26. AlEXANDER \& SALMON, supra note 8 at 349 .

27. Production-function is defined as the maximum amount of product that can be obtained from a specified combination of inputs. It shows the largest quantity of goods that any particular collection of inputs is capable of producing. William J. BAUMOL \& ALAN S. BLINDER, ECONOMICS: PRINCIPLES AND POLICIES 410 (1985).

28. JAMES S. COLEMAN ET AL., EQUALity OF EdUCATIONAL OPPORTUNITY (1966).

29. AlEXANDER \& SALMON, supra note 8 , at 351 .

30. Id. at 356, 359-61. The production-function model was first developed and applied to industry. Problems with applying the model to education include confusion about the relevant unit of production (individual pupil, classroom, school, or school district), and whether the chosen unit of production is "maximizing academic achievement or some other output." Id. at 356. Moreover, studies that apply the model do not identify an underlying theory of learning that defines the relationship between school inputs and academic achievement. Id. For example, the studies all "assume that teacher inputs can be measured by teacher characteristics," including education, experience and aptitude, and ignore the way in which these characteristics are actually implicated in the teaching-learning process. Id. (citing WADI D. HADDAD ET AL., EDUCATION AND DEVELOPMENT: EVIDENCE FOR NEW PRIORITIES 50 (1990)). 
analysis, and an inaccurate reflection of the "underlying behavioral reality." 31 Since then, several production-function studies addressed the flaws inherent when the model is applied to education, and found: (1) "[i]f family income [cannot] be changed, improvement in school outputs require[s] dramatic increases in inputs or significant changes in resource combinations;" (2) schools are incapable of improving the life outcomes of minorities without changing inefficiencies in expenditures for teacher experience and additional education; and (3) "money is important in producing higher student test scores when it purchases teachers with strong literacy skills, reduces class size to eighteen students per teacher, retains experienced teachers, and increases the number of teachers with advanced degrees." 32 These conclusions indicate that school finance is linked to student academic achievement.

Despite the ongoing debate, it is obvious to most that, at the very minimum, money can buy educational resources like instructional materials and equipment, new facilities, and increases in the number of highly trained teachers. It is also clear that communities, wealthy and poor alike, value the opportunities that additional money can buy. Indeed, Coons, Clune and Sugarman stated it best when they wrote:

We regard the fierce resistance by rich districts to reform as adequate testimonial to the relevance of money. Whatever it is that money may be thought to contribute to the education of children, that commodity is something highly prized by those who enjoy the greatest measure of it. If money is inadequate to improve education, the residents of poor districts should at least have an equal opportunity to be disappointed by its failure. ${ }^{33}$

If one agrees that differences in funding do affect the quality of education, it is clear that inequalities in the resources of school districts produce a wide range of educational opportunities afforded to students. It is a question of basic fairness to ensure that students are not penalized in terms of their education just because they are born into a family that is neither wealthy nor fortunate enough to live in a wealthy district. This issue, and the responsibility of a state to address it, is at the heart of the Zuni case.

31. Id. at 360

32. Id. at 361-62. See also William H. Clune, New Answers to Hard Questions Posed by Rodriguez: Ending the Separation of School Finance and Educational Policy by Bridging the Gap Between Wrong and Remedy, 24 CONN. L. REV. 721, 725-26 (1992) (arguing that, in well-conceived educational programs, additional financial input does produce substantial gains in student achievement).

33. John Coons et al., Private Wealth and Public Education 30 (1970). 


\section{B. New Mexico and School Finance Equity}

New Mexico depends on local property taxes to fund public school education. Like most states that depend on local taxes to fund public schools, differences in wealth among New Mexico's local education agencies (LEAs) ${ }^{34}$ have led to inequity in school funding. New Mexico has faced considerable challenges in its effort to address this inequity, including differences in the depth of district tax bases, poverty levels, and enrollment figures.

Overall, New Mexico ranks forty-eighth out of fifty states in per capita personal income, with $23.78 \%$ of public school age children living in poverty. ${ }^{35}$ The percent of school-age children living in poverty in the Los Alamos Public School District, however, is a considerably lower $2.53 \%{ }^{36}$ In contrast, the percentage of school-age children living in poverty in Zuni Public School District is $48.22 \%$; the percentage in Gallup-McKinley Public School District is $37.11 \%{ }^{37}$ In forty-nine of New Mexico's eighty-nine LEAs, the percentage is $25 \%$ or higher; twenty-six LEAs have percentages over $30 \%$, and seven LEAs have percentages over $40 \%{ }^{38}$

Variations in the number of students enrolled in schools across the state have also impeded efforts to equalize funding. Due to economies of scale, education costs may be higher in small districts, and research suggests that "size economies that reduce costs by more than one dollar per pupil do exist up to but not beyond 200 pupils." district in New Mexico is Albuquerque Public Schools, with 94,566 students. ${ }^{40}$ The smallest school district is the Mosquero district, with a population of fifty students. ${ }^{41}$

34. Throughout this article the terms "local education agencies" and "school districts" are used interchangeably.

35. NAT'L EDUC. AsS'N RESEARCH'S REPORT, RANKINGS \& ESTIMATES: RANKINGS OF THE STATES 2004 AND ESTIMATES OF SCHOOL STATISTICS 2005 (2005), available at http://164.64.166 .16/school.budget/nm.stat.05/Section\%20A/PDF\%20Files/A1.pdf; N.M. PUB. EDUC. DEP'T, Percent of Population Ages 4 to 17 Living in Poverty, By District (2006), available at http://www.ped.state.nm.us/div/ais/data/fs/03/05.06.poverty.dist.pdf.

36. N.M. PUB. EDUC. DEP'T, supra note 35.

37. Id.

38. Id.

39. ODDEN \& PiCUS, supra note 14 , at 231.

40. N.M. Pub. Educ. Dep't, Total Student Enrollment by District, School Year 2005-2006 (2006), available at http://www.ped.state.nm.us/div/ais/data/fs/05/05.06.enroll.dist.pdf.

41. Id. 
Despite these obstacles, New Mexico has remained committed to its diverse student population, ${ }^{42}$ and to providing educational services to students with differing needs. ${ }^{43}$ In the wake of the Supreme Court's decision in San Antonio Independent School District v. Rodriguez, ${ }^{44}$ a group of plaintiffs in New Mexico filed a lawsuit alleging that the state's education finance system, in which school funding expenditures varied widely based on the wealth of each school district, was in violation of New Mexico's constitution. ${ }^{45}$ The case settled before trial when New Mexico implemented the 1974 Public School Finance Act, which required the state to fund the operational costs of all school districts. ${ }^{46}$

The Act's funding formula is based on a model developed by the National Education Finance Project in the late 1960s and early 1970s, ${ }^{47}$ and includes a "state equalization guarantee distribution." 48 The distribution is "that amount of money distributed to each school district to ensure that the school district's operating revenue, including its local and federal revenues ... is at least equal to the school district's program cost." "49 "Program cost" is defined as the amount of money determined under New Mexico's funding formula "to be necessary for a given district with a particular configuration of students and educational programs to provide educational services." ${ }^{\text {50 }}$ The funding formula determines each district's program cost by using cost differentials to calculate the price associated with providing educational services to students with differing needs. ${ }^{51}$ The inclusion of these cost differentials

42. $31.1 \%$ of public-school students in the state are classified as "Anglo;" $54 \%$ are classified as Hispanic; $11.1 \%$ are classified as Native American; $2.5 \%$ are classified as Black; and $1.3 \%$ are classified as Asian. N.M. Pub. Educ. DeP'T, Percent of Student EnRollment Ethnic CATEGORY BY DisTRICT, SCHOOL YEAR 2005-2006 (2006), available at http://www.ped.state.nm. us/div/ais/data/fs/13/05.06.ethnic.pdf.

43. Brief for Respondent at 15, Zuni Pub. Sch. Dist. No. 89 v. U.S. Dep't of Educ., 127 S. Ct. 1534 (2007) (No. 05-1508), 2006 WL 3740364.

44. 411 U.S. 1 (1973).

45. Id. at $4-6$.

46. N.M. STAT. ANN. §§ 22-8-1 to -45 (West 2003 \& West Supp. 2006).

47. Sch. Budget \& Fin. Analysis Bureau, N.M. Pub. Educ. Dep'T, How New Mexico PUBLIC SCHOOLS ARE FUNDED 3 (2006), available at http://www.ped.state.nm.us/div/fin/ school.budget/how.nm.schools.are.fundedfy0806_files/How\%20NM\%20schools\%20are\%20funded FY0806.pdf.

48. N.M. STAT. ANN. § 22-8-25.

49. Id.

50. Sharon S. Ball \& J. Placido Garcia, New Mexico 6 (1999), available at http://nces .ed.gov/edfin/pdf/StFinance/NewMexi.pdf.

51. SCH. Budget \& Fin. AnAlysis Bureau, supra note 47, at 5. For example, research indicates that the cost of educating secondary school students is more than the cost to educate primary school students. Id. Moreover, additional funding may be required to provide bilingual education services to students with a high percentage of English-as-second-language speakers. Id. 
seeks to address vertical equity. The formula also makes adjustments for several other factors, including a district's "training and experience index," 52 the number of students served in nonprofit special education institutions, and the unique challenges faced by small, rural, or newly created school districts. ${ }^{53}$

The state equalization guarantee distributions are disbursed from the Public School Fund. ${ }^{54}$ When allocating the money, the state reduces its distribution to a particular district by an amount equal to $75 \%$ of what that district was independently able to raise through taxes. ${ }^{55}$ Funds are distributed in a non-categorical manner, and are not earmarked for specific programs. ${ }^{56}$ School districts are allowed to spend their funding according to local priorities as long as they stay within statutory guidelines. $^{57}$

The wealthiest school district in New Mexico enjoys per-pupil funding of $\$ 6520$, while the poorest district in the state has per-pupil funding of $\$ 2672$ - a difference of $144 \%{ }^{58}$ Outliers will always exist, however, because political concerns often make it unfeasible to eliminate all disparity by completely transferring the resources of one community to another. ${ }^{59}$ Indeed, when devising a school finance formula to equitably fund schools throughout the state, New Mexico sought to "equalize educational opportunity at the highest possible revenue level while minimizing the financial loss to the richest districts." $" 60$ Accordingly, despite the lingering outliers, New Mexico is lauded as having one of the most equalized funding formulas in the nation. ${ }^{61}$ The state's equalization guarantee distribution accounts for more than $90 \%$ of

52. BALL \& GARCIA, supra note 50, at 5. A district's training and experience index is based on the academic classifications and the experience levels of teachers in the district. Id.

53. Id. at 6 .

54. The Public School Fund also contains funding for district transportation costs, as well as supplemental costs like out-of-state tuition, emergency financial need distributions, and unexpected capital outlay emergencies. Id. at 2 .

55. Id. at 3. See also N.M. STAT. AnN. § 22-8-25(B) (West 2003 \& West Supp. 2006), BALL \& GARCIA, supra note 50, at 3.

56. Founds. for Great Pub. Schs., How Is New Mexico's Public School Budget CRAFTED AT THE STATE LEVEL? 2-3 (2004), available at http://nea-nm.org/PDF/sprtrn04materials /Crafting\%20the\%20State\%20Budget.pdf.

57. Id. at 3 .

58. Brief for the Petitioners at 20-21, Zuni Pub. Sch. Dist. No. 89 v. U.S. Dep't of Educ., 127 S. Ct. 1534 (2007) (No. 05-1508), 2006 WL 3350569.

59. See John Dayton, When All Else Has Failed: Resolving the School Funding Problem, 1995 BYU EDUC. \& L.J. 1, 5 (discussing the tension between the altruistic wish for education equity for all children and the self-interest of wanting the best for one's own children).

60. SCH. BUdGET \& Fin. ANALYSIS BUREAU, supra note 47, at 3.

61. NewRules.org, New Mexico's School Funding Formula, http://www.newrules.org/equity/ nmfund.html (last visited Aug. 18, 2007). 
operational revenue for school districts, and is the largest state distribution. ${ }^{62}$

\section{Federal Support for Equalization: Impact Aid}

The Federal government has recognized the impediment that taxexempt federal lands, such as Indian reservations, can pose to an LEA's efforts to raise money for public schools through property taxes. Congress addressed this problem by enacting the Impact Aid program in $1950 .^{63}$ The program provides funding to those school districts with compromised ability to levy taxes in support of public schools due to the presence of tax-exempt federal property within the district. ${ }^{64}$ The program also provides federal funds to local school districts to assist with the costs of providing "educational services to federally connected children." 65 "Federally connected children" are defined as those children whose parents are in the military, children who reside on Indian lands or federal property, and children whose parents are employed on federal property. ${ }^{6}$

As originally passed, the Impact Aid statute did not speak to whether a state could consider the Aid when allocating funding to LEAs. In 1968, Congress addressed this issue by amending the Impact Aid statute to prohibit states from taking into account the receipt of Impact Aid when allocating educational funding. ${ }^{67}$ In 1974, however, as states like New Mexico began efforts to equalize state funding, Congress became concerned that the "[i]nability to consider impact aid payments for the purposes of establishing an equalized level of expenditure seriously interfered with state plans for school finance reform." 68 Wanting to encourage state equalization efforts, Congress changed the Impact Aid program to include an exception: if a state administers a program that equalizes funding for school districts in the state, when determining funding allocations to each LEA the state may consider an LEA's receipt of Impact Aid and offset state funding accordingly. ${ }^{69}$ The purpose of the

62. SCH. BudGET \& Fin. ANALySis BurEAU, supra note 47, at 2.

63. Act of Sept. 30, 1950, Pub. L. No. 81-874, 64 Stat. 1106 (codified as amended at 20 U.S.C. $\S \S 7701-14(2000))$.

64. 20 U.S.C. $\$ 7701(1)(2000)$.

65. Id. $\$ 7701$.

66. Id. $\S 7701(2)-(5)$.

67. Id. $\S 7709(\mathrm{a})$.

68. S. REP. NO. 93-763, at 55 (1974)

69. 20 U.S.C. \& 7709(b)(1); H.R. REP. NO. 93-805, at 42 (1974), reprinted in 1974 U.S.C.C.A.N. 4093, 4128-29 ("The amendment adopted by the Committee will allow States to 
exception was to "prevent [I]mpact [A]id from hindering states' equalization efforts and [to prevent] duplicative compensation [to] school districts affected by federal activity (once by the federal government through impact aid and a second time by the state's equalization program).",70

When Congress amended the Impact Aid statute to allow states to consider Impact Aid payments as long as the state ensured that operational expenditures were equalized among LEAs, the job of determining whether a state was "equalized" was left to the Secretary of Education. $^{71}$ Accordingly, the Secretary promulgated regulations, the appendix of which outlined several steps for determining whether a state was equalized. First, LEAs within a state were to be ranked in order of per-pupil revenue. ${ }^{72}$ Second, the per-pupil revenue of the highest and lowest ranked LEAs would be compared to determine whether expenditures were indeed equalized throughout the state. ${ }^{73}$ If the disparity between the highest and lowest ranked LEAs was no more than $25 \%$, the state would be considered equalized. ${ }^{74}$

During the public notice and comment process, the Secretary expressed concern that outlier LEAs at the top and bottom of the ranked list would distort the true nature of a state's operational funding. ${ }^{75}$ Commentators proposed various methods to help minimize the impact of outliers, including (1) excluding districts above the ninety-fifth and below the fifth percentiles based on the number of districts ranked, or (2) excluding schools above the ninety-fifth and below the fifth percentiles based on the number of pupils in each of the ranked school districts. ${ }^{76}$

consider impact aid payments... as local resources under State equalization formulas if the Secretary of HEW determines that such formulas provide appropriate recognition of the relative tax resources per child to be educated which are available to local educational agencies.... The Committee has adopted this amendment because it believes that Federal education laws should not serve as an impediment to State actions designed to fulfill the judicial mandates and legislative actions removing the often close relationship between values of property and quality of education in a school district.").

70. U.S. Gen. Accounting Office, School Finance: State EfForts to Equalize FUNDING BETWEEN WeALTHY AND POOR SCHOOL DISTRICTS, 16 (1998), available at http://www.gao.gov/archive/1998/he98092.pdf.

71. Brief for the Federal Respondent at 3-4, Zuni Pub. Sch. Dist. No. 89 v. U.S. Dep't of Educ., 127 S. Ct. 1534 (2007) (No. 05-1508), 2006 WL 3742248 (citing 20 U.S.C. § 240(d)(2)(B), repealed by Pub. L. No. 103-382, providing that the term "equalize expenditures" would be "defined by the Secretary by regulation").

72. Id. at 4 .

73. Id.

74. Id. at $4-5$

75. Interim Regulations for Treatment of Payments Under State Equalization Programs, $41 \mathrm{Fed}$ Reg. 26,320, 26,323-24 (June 25, 1976).

76. Id. 26,323 . 
The Secretary rejected the former suggestion and decided that percentile cut-offs would be based on the number of pupils rather than the number of school districts. ${ }^{77}$ As justification, the Secretary noted that percentile cut-offs based on the number of districts would apply the disparity standard in an unfair and inconsistent manner among states. ${ }^{78}$ In states with a small number of large districts, an exclusion based on the percentage of school districts might exclude a substantial percentage of the pupil population, resulting in a comparison that would not accurately reflect the experience of a significant portion of students in the state. ${ }^{79}$ Conversely, in states with a large number of small districts, the same approach might exclude only an insignificant portion of the pupil population. $^{80}$

The Secretary's chosen formula was not without its own methodological infirmities. When applied to a state with a large number of small school districts, like New Mexico, an equalization formula that bases percentile cut-offs on student population will generally eliminate larger numbers of LEAs, making it more likely that disparities between school districts will be camouflaged. Despite this potential problem, the Secretary's formula was promulgated in 1976; the body of the regulation contained the permitted $25 \%$ disparity, whereas the equalization formula which addressed methodology was produced in an appendix. ${ }^{81}$ The Impact Aid statute itself did not codify any of the equalization standards or identify an equalization methodology.

An example is illuminating for purposes of understanding exactly how the Secretary's formula is applied. In fiscal year 2000, New Mexico had 317,777 students, and eighty-nine school districts. ${ }^{82}$ Those districts can be ranked in order of per-pupil expenditures. Mosquero district is ranked first, with a per-pupil revenue of $\$ 6520 .^{83}$ Des Moines district is ranked eighty-ninth, with a per-pupil revenue of $\$ 2672 .{ }^{84}$ If the equalization formula based percentile cut-offs on the number of school districts ranked, the first five and the last five districts would be disregarded so as to identify the per-pupil revenue for the LEA that serves pupils at the ninety-fifth and fifth percentile of the number of

7. Id. at 26,324 .

78. Id.

79. $I d$.

80. Id.

81. Brief for the Federal Respondent, supra note 71, at 4-6 (citing 34 C.F.R. § 222.63 (1993), regulations codifying the Secretary's formula under the later repealed $\S 240$ ).

82. Brief for the Petitioners, supra note 58, at 21.

83. See id.

84. See id. 
LEAs in the state. To determine disparity, the per-pupil revenue of the sixth-ranked Maxwell district, \$3591, and the per-pupil revenue of the eighty-fourth ranked Gadsden district, $\$ 2829$, would be compared. ${ }^{85}$ Because $\$ 3591$ exceeds $\$ 2829$ by more than $25 \%$, the state would be deemed un-equalized for purposes of Impact Aid.

What the Secretary's equalization formula requires instead, however, is that the ninety-fifth and fifth percentiles be determined by reference to a district's student population. ${ }^{86}$ The effect is to identify the per-pupil revenue for the LEA that serves pupils at the ninety-fifth and fifth percentiles of the student population in the state. Applied to New Mexico's eighty-nine LEAs, enough LEAs must be eliminated from the top of the ranking to account for 15,888 students, or as close to that figure as possible without going over. Similarly, enough LEAs have to be eliminated from the bottom of the ranking to account for 15,888 students, or as close to that figure as possible without going over. Under this formula, twenty-three LEAs are eliminated, and the per-pupil revenue of the eighteenth-ranked Penasco district, $\$ 3259$, is compared to the per-pupil revenue of the eighty-third-ranked Hobbs district, $\$ 2848 .{ }^{87}$ Because $\$ 3259$ exceeds $\$ 2848$ by only $14.43 \%$, New Mexico is considered equalized for purposes of Impact Aid.

In 1994 Congress re-authorized Impact Aid. This time, the statute itself codified the standards for determining whether a state's educational funding is equalized. ${ }^{88}$ The statute reads that a state is equalized if "the amount of per-pupil expenditure made by, or per-pupil revenues available to, the local educational agency in the State with the highest such per-pupil expenditures or revenues [does] not exceed the amount of such per-pupil expenditures made by, or per-pupil revenues available to, the local educational agency in the State with the lowest such expenditures or revenues by more than 25 percent." ${ }^{\prime 89}$ The statute further states that LEAs above the ninety-fifth or below the fifth percentile in per-pupil expenditures should be disregarded for purposes of determining disparity. ${ }^{90}$ Finally, when making determinations of equalization, the statute directs the Secretary to consider the additional costs a state incurs when providing education in unique school districts, such as those that

85. See id.

86. See Interim Regulations for Treatment of Payments Under State Equalization Programs, 41 Fed. Reg. 26,320, 26,324 (June 25, 1976).

87. See Brief for the Petitioners, supra note 58, at 20-21.

88. 20 U.S.C. $\$ 7709$ (2000).

89. Id. $\S 7709(\mathrm{~b})(2)(\mathrm{A})$.

90. Id. $\S 7709(\mathrm{~b})(2)(\mathrm{B})(\mathrm{i})$. 
are geographically isolated or have children with disabilities. ${ }^{91}$ Unlike the previous statute, which left equalization formulas entirely up to the Secretary, the language of this statute spoke directly to how equalization was to be determined. It did not reference the weighted ranking methodology that the Secretary had employed for eighteen years.

In September of 1995, the Secretary promulgated regulations in furtherance of the re-authorization. Those regulations reflected the statute's mandate that districts be ranked by per-pupil expenditures, and that LEAs with per-pupil expenditures or revenues above the ninety-fifth or below the fifth percentile would be disregarded for purposes of determining disparity. ${ }^{92}$ The regulations also, however, made reference to an appendix that outlined the "method for calculating the percentage of disparity." 93 This appendix essentially repeated the language from the 1976 appendix, and mandated that a weighted ranking based on the population of each school district in the state be made.

\section{Background and Procedural History of Zuni}

Zuni Public School District and Gallup-McKinley Public School District (collectively referred to as "Petitioners") challenged the Secretary's equalization formula. Petitioners also challenged the determination that New Mexico operates an equalized funding program which allows New Mexico to consider the Impact Aid received by both districts when determining state funding allocations. ${ }^{94}$ The Zuni Public School District is located entirely within the Pueblo of Zuni Reservation, and has virtually no tax base. ${ }^{95}$ Similarly, over $65 \%$ of the GallupMcKinley Public School District consists of Navajo Reservation lands that are "not taxable by state school districts." 96 At stake was Petitioners' share of approximately fifty million dollars in Impact Aid, an amount by which New Mexico currently offsets the districts' equalization distribution. ${ }^{97}$

91. Id. § 7709(b)(2)(B)(ii).

92. 34 C.F.R. $\$ 222.162(2007)$

93. Id.

94. Petition for Writ of Certiorari at 4, Zuni Pub. Sch. Dist. No. 89 v. U.S. Dep't of Educ., 127 S. Ct. 1534 (2007) (No. 05-1508), 2006 WL 1491269.

95. Id. at 2.

96. Brief for the Petitioners, supra note 58 , at 2 .

97. Id. at 4. The Impact Aid funding received by Petitioners accounts for almost one-half of all Impact Aid distributed to New Mexico LEAs. Brief for the Federal Respondent, supra note 71, at 10. 
A certification hearing to determine whether operational funding for public education in New Mexico was equalized for the 1999-2000 fiscal year was held in 1999. There, the Secretary of Education determined that New Mexico's funding scheme was equalized. ${ }^{98}$ Petitioners sought a hearing before a U.S. Department of Education administrative law judge to challenge both the method used to make the determination, and the determination itself. The judge upheld the Secretary's determination that New Mexico's funding scheme was equalized. ${ }^{99}$ Petitioners then appealed to the Secretary, who denied the appeal.

In 2004, Petitioners appealed to the Tenth Circuit Court of Appeals. A three judge panel issued an opinion in December of 2004 in which two of the three judges affirmed the Secretary's decision. ${ }^{100}$ Petitioners successfully petitioned for a rehearing en banc, and in February of 2006 a twelve member panel issued a one paragraph decision stating that the Secretary's decision was affirmed by virtue of an equally divided Court. ${ }^{101}$

Petitioners appealed from the Tenth Circuit's en banc decision. On September 26, 2006 the Supreme Court granted certiorari, and oral arguments in the case were heard on January 10, 2007. Oral arguments focused exclusively on the application of Chevron review to the case.

On April 17, 2007, the Supreme Court issued an opinion affirming the Tenth Circuit's decision. ${ }^{102}$ Writing for the Court, Justice Breyer explained that the history and purpose behind the Impact Aid statute rendered the Secretary's methodology reasonable. ${ }^{103}$ Moreover, the Secretary's methodology fell within the scope of the statute's plain language. ${ }^{104}$

98. In re Zuni Pub. Sch. Dist. No. 89, Docket No. 99-81-I (Dep't of Educ. April 17, 2001), available at http://www.ed-oha.org/cases/1999-81-i.html. Petitioners highlighted that the administrative law judge shared their concerns regarding the Secretary's formula as outlined in the appendix. Petition for Writ of Certiorari, supra note 94, at 7-8.

99. Id.

100. Zuni Pub. Sch. Dist. No. 89 v. U.S. Dep't of Educ., 393 F.3d 1158 (10th Cir. 2004), vacated en banc, 437 F.3d 1289 (10th Cir. 2006).

101. Zuni Pub. Sch. Dist. No. 89 v. U.S. Dep't of Educ., 437 F.3d 1289, 1290 (10th Cir. 2006), aff' $d, 127$ S. Ct. 1534 (2007). The failure of the panel to issue a decision one way or another has led to confusion as to why certiorari was granted in the case, particularly in light of the absence of a circuit split on the issue and the relatively small size of Impact Aid compared to other federal education programs. See Ebonne Ruffins, Zuni Public School District No. 89, et al. v. United States Department of Education, et al., Medill News Service, http://docket.medill.northwestern.edu/ archives/003885.php (last visited Sept. 15, 2007) (interviewing Leigh Manasevit, Special Assistant Attorney General for New Mexico).

102. Zuni Pub. Sch. Dist. No. 89 v. U.S. Dep’t of Educ., 127 S. Ct. 1534 (2007).

103. Id. at 1543 .

104. Id. 


\section{THE THEORETICAL UNDERPINNINGS OF CHEVRON REVIEW}

The Chevron case involved a challenge to the Environmental Protection Agency's (EPA) interpretation of the meaning of the phrase "stationary source" as found in the Clean Air Act Amendments of 1977. ${ }^{105}$ In 1981, the agency conducted a rulemaking proceeding and revised its interpretation of "stationary source" to refer to an entire plant. ${ }^{106}$ Referred to as the "bubble concept," 107 the effect was to allow a plant to increase pollution emissions from an individual pollution emitting device without triggering EPA intervention as long as net emissions for the plant were not increased as a whole. ${ }^{108}$ A plant could achieve this by increasing emissions from an individual pollution emitting device, while simultaneously decreasing emissions from another device. ${ }^{109}$ The D.C. Circuit determined that there was no clear definition of the phrase "stationary source" in the text or legislative history of the Clean Air Act. ${ }^{110}$ The D.C. Circuit went on to independently evaluate the EPA's interpretation ${ }^{111}$ and determined that the interpretation was inconsistent with the objectives of the Clean Air Act. ${ }^{112}$

In reversing the D.C. Circuit, the Supreme Court established a twopart test for reviewing an agency's statutory interpretation:

First, always, is the question whether Congress has directly spoken to the precise question at issue. If the intent of Congress is clear, that is the end of the matter; for the court, as well as the agency, must give effect to the unambiguously expressed intent of Congress. If, however, the court determines Congress has not directly addressed the precise question at issue, the court does not simply impose its own construction on the statute, as would be necessary in the absence of an administrative interpretation. Rather, if the statute is silent or ambiguous with respect to the specific issue, the question for the court

\footnotetext{
105. Chevron U.S.A., Inc. v. Natural Res. Def. Council, Inc., 467 U.S. 837, 839-40 (1984).

106. Id. at $857-59$.

107. Id. at 840; Natural Res. Def. Council, Inc. v. Gorsuch, 685 F.2d 718, 725 (D.C. Cir. 1982), rev'd on other grounds, 461 U.S. 956 (1983).

108. Natural Res. Def. Council, 685 F.2d at 720 n.1.

109. Id.

110. Id. at 723 .

111. Id. at 725 ("[T] $]$ he central issue confronting us is whether EPA's discretion under the Clean Air Act is sufficiently broad to allow it to apply the bubble concept to the nonattainment program.").

112. Id. at 726-27 ("[W]e must conclude that the bubble concept may not be employed in [the nonattainment provisions of the Clean Air Act]. The nonattainment program's raison d'etre is to ameliorate the air's quality in nonattainment areas .... This purpose ... rules out application of the bubble concept to the nonattainment program." (internal citation omitted)).
} 
is whether the agency's answer is based on a permissible construction of the statute.

The Court further elaborated that gaps and ambiguities in statutes indicate an "implied" delegation ${ }^{114}$ of interpretive authority. ${ }^{115}$

Because of the two-part test it articulated, Chevron has been described as "one of very few defining cases... in American public law."116 Chevron fundamentally impacted the relationship between courts and agencies in administrative law, despite the intention of the test's creators to issue a routine environmental law opinion. ${ }^{117}$ If Congress has not directly spoken, a court using Chevron review defers to an agency's interpretation of a statute as long as the interpretation is a "permissible construction of the statute."118 Courts have used various tests to determine what constitutes a "permissible construction," including examining whether an interpretation is consistent with a statute's plain language or meaning, ${ }^{119}$ underlying congressional intent or purpose, ${ }^{120}$ or legislative history. ${ }^{12}$

Chevron review, however, also recognizes agency expertise and political accountability. ${ }^{122}$ The Court has noted that deference to an

113. Chevron U.S.A., Inc. v. Natural Res. Def. Council, Inc., 467 U.S. 837, $842-43$ (1984) (internal citations omitted).

114. The assertion that ambiguity is an implied delegation has been challenged. See, e.g., Cass R. Sunstein, Interpreting Statutes in the Regulatory State, 103 HARV. L. REV. 405, 445 (1989) (“A rule of deference in the face of ambiguity would be inconsistent with understandings, endorsed by Congress, of the considerable risks posed by administrative discretion. An ambiguity is simply not a delegation of law-interpreting power. Chevron confuses the two." (internal citation omitted))

115. Chevron, 467 U.S. at 843-44. Prior to Chevron, courts were said to only have a duty to defer when Congress expressly delegated authority to an agency to " "define a statutory term or prescribe a method of executing a statutory provision."' Thomas W. Merrill \& Kristin E. Hickman, Chevron's Domain, 89 GEO. L.J. 833, 833 (2001) (quoting United States v. Vogel Fertilizer Co., 455 U.S. 16, 24 (1982))

116. Cass R. Sunstein, Law and Administration After Chevron, 90 Colum. L. REV. 2071, 2075 (1990).

117. Ironically, scholars have noted that the Chevron court never intended for the case to so fundamentally impact the law of deference, and that papers of the late Justice Thurgood Marshall contain no evidence that any justice considered the case any more than a routine opinion in environmental law. Ronald M. Levin, The Anatomy of Chevron: Step Two Reconsidered, 72 CHI.KENT L. REV. 1253, 1257 (1997) (referring to the research in Robert V. Pervical, Environmental Law in the Supreme Court: Highlights from the Marshall Papers, 23 ENVTL. L. REP. 10,606, 10,613 (1993)).

118. Chevron, 467 U.S. at 843 .

119. Nat'l R.R. Passenger Corp. v. Boston \& Me. Corp., 503 U.S. 407, 417 (1992).

120. INS v. Cardoza-Fonseca, 480 U.S. 421, 453 (1987).

121. NationsBank of N.C., N.A. v. Variable Annuity Life Ins. Co., 513 U.S. 251, 257 (1995).

122. The Chevron case itself made only implicit reference to agency expertise as a rationale for judicial deference, writing that the regulatory scheme at issue was "technical and complex," and that 
agency's permissible construction of a statute is justified in part because of an agency's greater familiarity with constantly changing facts and circumstances surrounding the issue being regulated. ${ }^{123}$ Moreover, in areas where the subject matter of a statute is technical or complex, agencies are particularly authorized to fill in gaps where statutes are silent. ${ }^{124}$ The Court has also noted that although "agencies are not directly accountable to the people, the Chief Executive is."125 Accordingly, it is appropriate for executive agencies to make policy choices and address competing interests that Congress either failed to resolve or intentionally left to the agency for administration. ${ }^{126}$

\section{APPLYING CHEVRON REVIEW TO ZUNI}

\section{A. The Application of Chevron Review in Zuni}

Supreme Court briefs and oral argument in Zuni focused exclusively on whether the Secretary's determination should be given Chevron deference. $^{127}$ Recent Supreme Court jurisprudence, however, has complicated determinations of when Chevron review applies to administrative decisions. Coined "step-zero" analysis, scholars have identified three cases in which the Court has attempted to clarify the

Congress may have "consciously desired the [agency] to strike the balance ... thinking that those with great expertise and charged with responsibility for administering the provision would be in a better position to do so." Chevron, 467 U.S. at 865 .

123. FDA v. Brown \& Williamson Tobacco Corp., 529 U.S. 120, 132 (2000). See also Balt. Gas \& Elec. Co. v. Nat'l Res. Def. Council, 462 U.S. 87, 103 (1983) (noting the well established rule that when a court is reviewing predictions within an agency's area of special expertise, at the frontiers of science, the "court must generally be at its most deferential").

124. Nat'l Cable \& Telecomm. Ass'n, Inc. v. Gulf Power Co., 534 U.S. 327, 339 (2002) (citing Chevron, 467 U.S. at 843-44).

125. Chevron, 467 U.S. at 865.

126. Id. at 864-66. See also Elena Kagan, Presidential Administration, 114 Harv. L. Rev. 2245, 2375-77 (2001) (arguing that the degree of deference given to an agency should be based on presidential influence on agency action, as indicated by whether the agency is independent of the executive branch; higher levels of presidential involvement with executive branch agencies warrant higher degrees of deference).

127. The question presented on certiorari was:

Whether the Secretary has the authority to create and impose his formula over the one prescribed by Congress and through this process certify New Mexico's operational funding for fiscal year 1999-2000 as "equalized," thereby diverting the Impact Aid subsidies to the State and whether this is one of the rare cases where this Court should exercise its supervisory jurisdiction to correct a plain error that affects all State school districts that educate federally connected children.

Supreme Court Docket, http://www.supremecourtus.gov/qp/05-01508qp.pdf (last visited Sept. 12, 2007) 
applicability of Chevron analysis: ${ }^{128}$ Christensen v. Harris County, ${ }^{129}$ United States v. Mead Corp. ${ }^{130}$ and Barnhart v. Walton. ${ }^{131}$

Christensen involved the validity of an opinion letter issued by the Department of Labor concerning compensatory time. The Court determined application of the Chevron framework was unwarranted because, similar to policy statements or enforcement guidelines, the letter lacked the force of law and could be distinguished from those interpretations arrived at after "formal adjudication or notice-andcomment rulemaking." 132

Mead further clarified the relationship between agency rulemaking and the processes used by agencies to interpret statutes. Deciding that a tariff ruling by the United States Custom Service was not entitled to Chevron deference, the Court explained that Chevron analysis was applicable when "it appears that Congress delegated authority to the agency generally to make rules carrying the force of law, and that the agency interpretation claiming deference was promulgated in the exercise of that authority." 133 A good indication of such delegation is congressional authorization to "engage in the process of rulemaking or adjudication that produces regulations or rulings for which deference is claimed." 134 Mead also noted, however, that Chevron analysis might be applicable even when formal procedures were not employed by the agency. ${ }^{135}$

Finally, Barnhart built upon the principle in Mead which suggested that Chevron analysis might be applicable even when an agency did not use formal procedures and the "agency's actions lacked the force of law." "136 In ruling that the Social Security Administration's initial use of less formal procedures to develop regulations did not preclude Chevron deference, the Court explained that Chevron deference would depend on the "interpretive method used and the nature of the question at issue."137 Writing for the Court, Justice Breyer rejected a simple deference rule, and instead advocated for a case-by-case inquiry which would examine "the interstitial nature of the legal question, the related expertise of the

\footnotetext{
128. Cass R. Sunstein, Chevron Step Zero, 92 VA. L. Rev. 187, 211 (2006).

129. 529 U.S. $576(2000)$.

130. 533 U.S. 218 (2001).

131. 535 U.S. 212 (2002).

132. Christensen, 529 U.S. at 587.

133. Mead, 533 U.S. at 226-27.

134. Id. at 229 .

135. Id. at 231 .

136. Sunstein, supra note 128 , at 216.

137. Barnhart v. Walton, 535 U.S. 212, 222 (2002).
} 
Agency, the importance of the question to administration of the statute, the complexity of that administration, and the careful consideration the Agency has given the question over a long period of time ....",138

Taken together, the three cases suggest that the application of the Chevron framework, and the ultimate extension of Chevron deference, will depend on Congress' instructions in a particular statutory scheme. Although the "grant of authority to act with the force of law" is sufficient, it is not a necessary condition for a court to "find that Congress has granted an agency the power to interpret ambiguous" statutes. ${ }^{139}$

The Secretary of Education is authorized by law to "make, promulgate, issue, rescind, and amend rules and regulations" in order to govern programs administered by the Department of Education and carry out functions vested in the Secretary by law. ${ }^{140}$ At issue in Zuni was the Secretary's interpretation through regulation of the Impact Aid statute the Department is charged with administering. As such, Zuni involved the type of rulemaking through regulation which was recognized in Mead as warranting Chevron analysis. Although the Secretary declined to follow notice-and-comment rulemaking procedures when promulgating the regulations at issue, the APA's "good cause" exemption allows agencies to make rules that are binding and have the force of law, even without a notice-and-comment process. ${ }^{141}$ In this case, the Secretary utilized the exemption. ${ }^{142}$

Moreover, the Impact Aid Statute explicitly directs the Secretary of Education to determine whether a state has a program in effect that equalizes expenditures for public education, and if so, to certify that state's program as equalized. ${ }^{143}$ Only then may a state offset their education funding to a district by the amount of Impact Aid received by

\footnotetext{
138. Id.

139. Sunstein, supra note 128 , at 218.

140. 20 U.S.C. $\S 1221 \mathrm{e}-3$ (2000) ("The Secretary, in order to carry out functions otherwise vested in the Secretary by law or by delegation of authority pursuant to law, and subject to limitations as may be otherwise imposed by law, is authorized to make, promulgate, issue, rescind, and amend rules and regulations governing the manner of operation of, and governing the applicable programs administered by, the Department.").

141. 5 U.S.C. $\S 553(b)(3)(B)(2000)$.

142. Brief for Respondent, supra note 43 , at 42.

143. See 20 U.S.C. $§ 7709$ (b)(1) (2000) (“A State may reduce aid to a local educational agency that receives a payment under [Impact Aid] . . . if the Secretary determines ... that the State has in effect a program of State aid that equalizes expenditures for free public education among local educational agencies in the State."); id. § 7709(b)(2)(B) ("In making a determination under this subsection, the Secretary shall...."); id. § 7709(c)(3)(A) ("If the Secretary determines that a program of State aid qualifies under subsection (b) of this section, the Secretary shall certify the program and so notify the State.").
} 
that district. These adjudications carry the force of law, as they are binding on the states. In this sense, the Secretary is engaging in the type of adjudication that was also recognized in Mead as warranting Chevron analysis.

In light of the rulemaking and adjudicatory nature of the Secretary's actions, the application of Chevron analysis to the Zuni case was appropriate. Accordingly, the Court's opinion focused on the two prongs of Chevron review: (1) whether Congress spoke directly to how equalization was to be determined in the Impact Aid Statute; and (2) assuming Congress was silent or ambiguous regarding equalization determinations, whether the Secretary's determination was a permissible and reasonable interpretation of the statute. ${ }^{144}$

Application of Chevron review to the Zuni case was not simple, despite the doctrine's seemingly straightforward two-part test. Briefs filed in the Supreme Court, as well as oral argument, focused heavily on the first prong of Chevron: whether Congress had spoken directly to the method which must be used for purposes of determining whether a state operates an equalized education system. ${ }^{145}$ Petitioners' brief argued that the explicit language used by Congress in the 1994 statute requires that the Secretary disregard LEAs with per-pupil expenditures or revenues above the ninety-fifth and below the fifth percentile of such expenditures in the state. ${ }^{146}$ Accordingly, an equalization formula that requires a weighted ranking of LEAs based on population is in direct contradiction with congressional intent and is completely precluded by the language of the statute. ${ }^{147}$ Petitioners pointed out that counsel for both the Department and New Mexico admitted to this conflict during the administrative hearing on the issue. ${ }^{148}$

Petitioners also argued that even if Congress was not entirely clear, and the second step of Chevron review was warranted, traditional tools of statutory construction, including performing a "natural reading," considering "interpretive clues" from Congress, and viewing the statute in its "textual setting," all illustrate that as of 1994 the Secretary was

\footnotetext{
144. Chevron U.S.A., Inc. v. Natural Res. Def. Council, Inc., 467 U.S. 837, 842-43 (1984).

145. See generally Brief for Respondent, supra note 43.

146. Brief for the Petitioners, supra note 58 , at $14-15,31$.

147. Id. at 37 .

148. Id. at 25-26 (noting that Department counsel explained that the only way in which ambiguity in the language of the Impact Aid statute could be proven was by reference to the statutory purpose of the program, and that New Mexico Department of Education's counsel admitted that, on its face, the Department's regulations were "probably not" consistent with the language of the Impact Aid statute).
} 
precluded from using his weighted average. ${ }^{149}$ Petitioners noted that Congress was aware that the Secretary used a weighted formula and could have easily adopted language incorporating the formula into the statute but declined to do so. ${ }^{150}$ Moreover, because the two formulas are mutually exclusive, it was unlikely that Congress could have implicitly contemplated the weighted average. ${ }^{151}$ Finally, the Secretary's formula was completely at odds with Congress' intent to ensure that LEAs eligible to receive Impact Aid actually receive the benefit of that Aid unless the state's educational funding is equalized. ${ }^{152}$ Therefore, the Secretary's interpretation was not "permissible." "153

To the extent that Chevron and its progeny reinforced the cardinal rule that Chevron review begins first with an examination of the text, a plain reading of the Impact Aid statute seems to reinforce Petitioners' position. In response, however, New Mexico and the U.S. Department of Education argued that the language of the statute did not unambiguously answer the "precise question at issue." 154 That is, statutory language did not address "whether, when applying the [ninety-fifth] and [fifth] percentile exclusions set forth in the statute, the Secretary is required to eliminate [five percent] of the LEAs from each end of the spectrum ... or instead may eliminate the outlying five percentiles of pupils." 155 Furthermore, New Mexico argued that the language of the Impact Aid statute was ambiguous. Although the statute instructs the Secretary to disregard LEAs with per-pupil expenditures above and below certain percentiles, the statute does not specify a methodology for doing so. ${ }^{156}$ The statute neither provides the Department with directions for determining the ninety-fifth and fifth percentiles of "per-pupil revenues," nor makes clear what is meant by the phrase "per-pupil expenditures or revenues above the ninety-fifth or below the fifth percentile of those expenditures or revenues in the State."157 What Petitioners failed to consider, argued New Mexico, is that "per-pupil revenues in the state" may refer to all per-pupil revenues for which each LEA is responsible. ${ }^{158}$

\footnotetext{
149. Id. at 31-33 (citing Gen. Dynamics Land Sys., Inc. v. Cline, 540 U.S. 581, 586, 597 (2004)).

150. Id. at 35

151. Id. at $36-37$.

152. Id. at 37,46 .

153. Id. at $45-46$.

154. Brief for the Federal Respondent, supra note 71, at 19-20; Brief for Respondent, supra note 43 , at $22-23$.

155. Brief for the Federal Respondent, supra note 71, at 19-20 (citation and emphasis omitted).

156. Brief for Respondent, supra note 43, at 23.

157. Id.

158. Id. at $20,25-26$.
} 
Accordingly, every student in the state has a "per-pupil revenue" which must be accounted for in the equalization formula. ${ }^{159}$

The rest of New Mexico's arguments were devoted to proving that the Secretary's interpretation was indeed permissible under step two of Chevron review, and made heavy use of legislative history and congressional intent analysis. New Mexico noted that the Secretary historically maintained three regulatory options under which a state could qualify as equalized, and that it was at the Secretary's request that Congress even altered the Impact Aid regulatory scheme in $1994 .{ }^{160}$ In fact, the Secretary drafted what would become the language of the reenacted Impact Aid program, and that language suggested an equalization method would be placed in the appendix. ${ }^{161}$ As such, despite the language of the statute, it would be illogical to believe that the Department was rejecting its own disparity test, or advocating that Congress adopt a disparity test based on a formula the Secretary had already rejected in $1976 .{ }^{162}$ Rather, the Secretary's intent to include a weighted ranking in the equalization formula based on student population was imputed to Congress. ${ }^{163}$ Moreover, New Mexico argued that the statutory scheme as a whole supports the Secretary's interpretation as illustrated by the fact that Impact Aid awards are calculated using a method which considers the pupil population of an LEA. ${ }^{164}$ Finally, Petitioners' formula removed only ten LEAs for purposes of determining equalization. ${ }^{165}$ According to New Mexico, the results of Petitioners' formula amounted to an insignificant portion of the student population and failed to completely eliminate anomalous outliers. ${ }^{166}$

The Department of Education, as federal respondent, made an additional statutory construction argument in support of the Secretary's interpretation. The same Act through which Congress enacted Impact Aid also enacted the Education Finance Incentive Grant Program (EFIG). EFIG is another program that seeks to encourage equitable education

\footnotetext{
159. Id. at $25-26$.

160. Id. at 10 .

161. Brief for the Federal Respondent, supra note 71, at 6-8.

162. Id. at $30-31$.

163. Id.

164. Brief for Respondent, supra note 43, at 27-30.

165. Brief for the Federal Respondent, supra note 71, at 11-12.

166. Brief for Respondent, supra note 43, at 29-30; Brief for the Federal Respondent, supra note 71 , at $31-32$.
} 
funding within states. ${ }^{167}$ Not only does the statutory language of EFIG require the Secretary to consider the number of pupils in each LEA when assessing expenditure disparity, ${ }^{168}$ but the EFIG program also extends favorable treatment to a state as long as that state meets the disparity standard described in the regulations promulgating the 1994 Impact Aid program. ${ }^{169}$ To be sure, the language of the EFIG statute makes reference only to the body of the Impact Aid regulations, and makes no reference to the weighted ranking requirement included in the appendix of the regulations. ${ }^{170}$ Nevertheless, the Department of Education considered the reference to Impact Aid regulations as encompassing the appendix, and argued that Congress could not be considered to have explicitly endorsed the Secretary's Impact Aid formula for EFIG, but implicitly prohibited it under the Impact Aid program. ${ }^{171}$

\section{B. The Court's Opinion}

The Court's decision largely mirrored the arguments made by Respondents in their briefs and at oral argument, and focused primarily on whether discretion to choose an equalization formula had been delegated to the Department. ${ }^{172}$ Writing for the majority, and joined by Justices Stevens, Kennedy, Ginsburg and Alito, Justice Breyer employed a tortured interpretation of the Chevron review doctrine to decide that the Secretary's interpretation and methodology was both reasonable and within the scope of the Impact Aid statute's plain language. ${ }^{173}$ The Court broke Chevron's rule requiring that analysis begin with whether

167. 20 U.S.C. $\S 6337$ (2000). See also Brief for the Federal Respondent, supra note 71, at 2829 ('Grants to States under EFIG are based on an 'equity factor,' which-like the equalization test in the Impact Aid statute - aims to measure the degree of variation in per-pupil expenditures among a State's LEAs.").

168. 20 U.S.C. $\S 6337($ b)(3)(A)(ii)(II) ("Variation[:] In computing coefficients of variation, the Secretary shall weigh the variation between per-pupil expenditures in each local educational agency and the average per-pupil expenditures in the State according to the number of pupils served by the local educational agency.").

169. See id. $\S 6337(b)(3)(B)$ ("Special rule[:] The equity factor for a State that meets the disparity standard described in section 222.162 of title 34, Code of Federal Regulations . . ..").

170. See 34 C.F.R. § 222.162(a)(2007) ("Percentage disparity limitation[:] The Secretary considers that a State aid program equalizes expenditures if the disparity in the amount of current expenditures or revenues per pupil for free public education among LEAs in the State is no more than 25 percent. In determining the disparity percentage, the Secretary disregards LEAs with per pupil expenditures or revenues above the 95th or below the 5 th percentile of those expenditures or revenues in the State. The method for calculating the percentage of disparity in a State is in the appendix to this subpart.").

171. Brief for the Federal Respondent, supra note 71, at 30.

172. See generally Zuni Pub. Sch. Dist. No. 89 v. U.S. Dep't of Educ., 127 S. Ct. 1534 (2007).

173. Id. at 1544 . 
Congress has spoken directly to the question at issue through the statutory language. ${ }^{174}$ Instead, the Court first considered the reasonableness of the Secretary's interpretation. ${ }^{175}$ After considering the history and "basic purpose" of Impact Aid, ${ }^{176}$ the Court noted that calculations for determining whether a state is "equalized" are the type of "highly technical, specialized interstitial matters" that Congress delegates to specialized agencies. ${ }^{177}$ Second, the failure of any member of Congress to criticize the Secretary's methodology or suggest a revision illustrated historical support for the Secretary's interpretation. ${ }^{178}$ Finally, the Secretary's formula was methodologically sound in ensuring the adequate elimination of outliers that may skew disparity determinations. ${ }^{179}$

After establishing reasonableness, the Court addressed the plain language of the Impact Aid statute. ${ }^{180}$ According to the Court, the phrase "above the 95th percentile... of ... [per pupil] expenditures," when taken with "absolute literalness," limits the Secretary to calculation methods that involve "per-pupil expenditures." 181 The Court went on to explain that the word "percentile" refers to the distribution of "some population into 100 parts." 182 Although the statute mandated which relevant characteristic (per pupil expenditure) must be used to create cutoffs in that distribution, the statute did not specify which population is to be distributed. ${ }^{183}$ This ambiguity was further highlighted by the fact that the statute concerns both students and school districts. ${ }^{184}$ As such, the Secretary was free to define the population, in this case defining it by number of students instead of by number of LEAs. This grant of discretion to the Secretary was supported by the fact that Congress had avoided comparable ambiguity in other statutes by explicitly identifying the relevant population. The use of more general language in the Impact Aid statute gave the Secretary the "authority to resolve such subsidiary

174. See Chevron U.S.A., Inc., v. Natural Res. Def. Council, Inc. 467 U.S. 837, 842 (1984) ("First, always, is the question whether Congress has directly spoken to the precise question at issue." (emphasis added)).

175. Zuni, 127 S. Ct. at $1540-41$.

176. Id. at 1541 .

177. Id.

178. Id.

179. Id. at $1541-43$.

180. Id. at 1543 .

181. Id.

182. Id.

183. Id. at 1544 .

184. Id. at 1546. 
matters at the administrative level."185 Finally, the Court drew reassurance from the failure of any statistician to challenge the Court's reading. ${ }^{186}$

Justice Scalia penned a dissent, joined by Chief Justice Roberts and Justice Thomas, and partially joined by Justice Souter, in which he characterized the majority's reasoning as the "elevation of judgedsupposed legislative intent over clear statutory text," made obvious by a majority opinion which begins with the second, instead of the first, step of Chevron review. ${ }^{187}$ As an initial matter, the Secretary's implementing regulations did not resemble the Impact Aid statute, placing them at odds with the statutory language. Moreover, there was no ambiguity regarding which population is to be used for distribution, as the statute makes clear that LEAs are the only relevant population and "makes no mention of student population whatsoever." " Furthermore, the majority considered statutory context and erroneously concluded that Impact Aid is about both students and school districts. Rather, the Impact Aid statute focuses on LEAs instead of number of pupils, and includes an equalization formula designed to address funding disparities between LEAs, and not individual students. ${ }^{189}$

Justice Scalia went on to note that the only thing about congressional intent that can be known for sure is that both Houses of Congress agreed upon the text of the statute. ${ }^{190}$ In addition, Congress specifically incorporated student population into disparity determinations in other parts of the Act containing the Impact Aid statute. As such, Congress could have done the same thing with Impact Aid, and chose not to. ${ }^{191}$ Justice Scalia further argued that by constructing a congressional intent that was not reflected in the legislative record, the majority not only unfairly expected schools to "pore over some 30 years of regulatory history to divine Congress's 'real' objective," but also "deprive[d] legislators of the assurance [that their use] of ordinary terms ... will be given a predictable meaning.,"192

Regarding methodology, Justice Scalia argued that the Court lacked school finance expertise sufficient to affirm the desirability of a

185. Id. at 1545

186. Id. at 1546

187. Id. at 1551

188. Id. at 1553 .

189. Id. at 1555 .

190. Id. at 1556 .

191. Id. at 1558 .

192. Id. at 1557. 
methodology that resulted in the elimination of approximately onequarter of New Mexico school districts from a disparity determination. ${ }^{193}$ Finally, Justice Scalia argued that the majority's concerns regarding outliers was unfounded, as parts of the statute specifically direct the Secretary to consider those aspects of state aid programs that consider the additional costs of providing education in unique districts. ${ }^{194}$

Justice Souter wrote a separate dissenting opinion in which he conceded that Congress probably intended for the Secretary to continue to follow the disparity methodology devised prior to re-authorization of the Impact Aid statute. ${ }^{195}$ Nevertheless, for the reasons explained in Justice Scalia's dissent, the language of the statute was unambiguous and in contradiction with the Secretary's methodology. ${ }^{196}$

\section{THE CONSTRAINTS OF CHEVRON REVIEW}

Missing from the briefs submitted in the case, the oral arguments, and the Court's opinions, is detailed discussion about the effects of the equalization formulas on New Mexico public schoolchildren in terms of horizontal equity, vertical equity, or adequacy. ${ }^{197}$ Briefs submitted to the Court neither assessed whether the Secretary's interpretation has detrimental effects on education finance in the two challenging districts, nor inquired whether the Secretary's formula potentially masks an unequalized education funding scheme. Both outcomes would be contrary to congressional intent in enacting Impact Aid.

Briefs also neglected to address the failure of the Secretary to engage in notice-and-comment rulemaking after the changes to statutory language in 1994, ${ }^{198}$ and never explored the sincerity of the Secretary's

\footnotetext{
193. Id. at 1559 .

194. Id.

195. Id. (Souter, J., dissenting).

196. Id.

197. Only an amicus brief submitted by fifty-four New Mexico public school districts in support of Respondents draws the Court's attention to possible funding losses that will be incurred by other school districts if New Mexico is deemed un-equalized, is no longer allowed to consider Impact Aid in its funding allotments, and thereafter fails to find additional funding to offset the loss. The brief goes on to primarily argue that a sudden change in status would be harmful to school districts, and requests the Court grant only prospective relief. Motion for Leave to File a Brief as Amici Curiae and Brief of Amici Curiae Public School Districts in Support of Respondents at 11-12, 32-33, Zuni Pub. Sch. Dist. No. 89 v. U.S. Dep’t of Educ., 127 S. Ct. 1534 (2007) (No. 05-1508), 2006 WL 3742249 .

198. The Department maintains that it declined to engage in notice-and-comment procedures because the regulations were essentially a "re-issuance of regulations that had initially been promulgated in 1976, and those preexisting regulations were issued through notice-and-comment procedures." Brief for the Federal Respondent, supra note 71, at 40.
} 
assertion that the interpretation allows for the most consistent determination of disparity from state to state. The fact that only three states, New Mexico, Kansas, and Alaska, even aspire to prove equalized funding for purposes of Impact $\mathrm{Aid}^{199}$ begs the question of why the Secretary cannot make determinations of equality on a case-by-case basis, thus avoiding the problem of potentially masking funding inequalities.

Oral argument, which focused almost entirely on the doctrinal parameters of Chevron review, did not fare any better than the briefs. The hour largely mirrored briefs submitted in the case, and was limited to the question of whether Congress actually spoke to the precise question at issue, debates on what could be gleaned from legislative history, and the definition of the word "percentile." 200 The latter topic created mass confusion among the Justices. ${ }^{201}$ The Court's majority and dissenting opinions continued the trend, analyzing congressional intent, and completely ignoring questions of equity.

The nearly exclusive focus on the purely doctrinal aspects of Chevron review in the case was overwhelmingly constraining. The parties' efforts to decide "who gets to decide" led to a complete failure to understand the policy implications of the formulas at the level where it counts - public school education in New Mexico. The constraints of Chevron review also eclipsed an opportunity for the Department to prove that its decision-making process was comprehensive, that it brought agency expertise to bear in making a decision, and that congressional goals were achieved through the Department's interpretation.

The narrow presentation of the case was particularly problematic as the Court proceeded to step two of Chevron analysis. Conflicting but equally plausible interpretations of the plain language and legislative history of the Impact Aid statute allowed the majority to determine that Congress did not speak directly to the question at issue. ${ }^{202}$ This was no

199. Id. at 9 n.2.

200. See generally Transcript of Oral Argument, Zuni, 127 S. Ct. 1534 (No. 05-1508).

201. See, e.g., id. at 11 (Justice Breyer: "What are, what is it we are distributing? A simple question, I guess, for a statistician. I unfortunately am not one and can't find one, so I have no idea what this statute means").

202. Scholars have opined as to how much clarity, or lack thereof, a Court must encounter before moving to step two of Chevron review. For example, Mark Seidenfeld, A Syncopated Chevron: Emphasizing Reasoned Decisionmaking in Reviewing Agency Interpretations of Statutes, 73 TEX. L. REV. 83, 94-95 (1994), notes that deferential courts, who read Chevron as a strong signal from the Supreme Court that courts should not interfere with agency interpretation unless the statute clearly expresses a contrary meaning on the precise question at issue, generally find statutes silent or ambiguous at step one, and tend to affirm agency interpretations at step two. In contrast, active courts read Chevron as a limited suggestion that Courts may overturn an agency interpretation only 
surprise, as even Petitioners admitted during the administrative hearing that the statute "may be ambiguous [as] to the precise formula that is to be used." 203 At the second prong of review, the Court was tasked with determining whether the Secretary engaged in a "permissible" interpretation of the Impact Aid statute. Unable to glean a clear answer from legislative history or plain meaning of the statute, the determination of whether the interpretation was "permissible" should have involved an inquiry into whether the effects of the Secretary's interpretation were in line with congressional intent upon enacting Impact Aid. ${ }^{204}$ Once there, however, the Court had insufficient information to properly determine whether the Secretary's decision-making process was thorough, and whether the Secretary's interpretation, in both theory and practice, furthered congressional intent.

\section{A. Congressional Intent and Policy Implications}

As discussed earlier, Chevron review strikes a balance between deference to congressional intent and deference to agency expertise in the policy arena. The Chevron court emphasized the latter when noting that "policy arguments are more properly addressed to legislators or administrators, not to judges." 205 Even when, however, Congress is deemed to have delegated policy decisions to agencies through ambiguous statutory language, the agency's policy decisions must still be reasonable in light of congressional intent; those policy decisions must be consistent with a statute's underlying purpose, ${ }^{206}$ plain meaning, ${ }^{207}$ or legislative history. ${ }^{208}$ In light of this mandate, a policy decision by an

if the court is certain about congressional intent regarding the meaning of the statute. Id. Accordingly, active courts tend to find statutes clear at step one of Chevron review, and reach step two less often. Id. Another commentator, Gary Lawson, Proving the Law, 86 Nw. U. L. REV. 859, 874-75 (1992), argues Courts must know what counts as evidence of a statute's meaning, how significant the evidence is, and when enough evidence has been gathered to warrant a legal truth about statutory meaning. Once such theories are established, the answer to the question of statutory meaning varies based on the standards of proof required. Id. at 875-77. "How Clear is Clear" in Chevron's Step One?, 118 HARV. L. REV. 1687, 1692-94 (2005) argues that at step one of Chevron review, courts should consider the institutional preferences of Congress when deciding what level of clarity is needed to determine whether Congress spoke clearly to the precise issue in question.

203. Zuni Pub. Sch. Dist. No. 89 v. U.S. Dep't of Educ., 393 F.3d 1158, 1167 (2004) (quoting record), vacated en banc, 437 F.3d 1289 (10th Cir. 2006).

204. See INS v. Cardoza-Fonseca, 480 U.S. 421, 445 n.29 (1987) (discussing Chevron analysis).

205. Chevron U.S.A., Inc. v. Natural Res. Def. Council, Inc., 467 U.S. 837, 864 (1984).

206. Cardoza-Fonseca, 480 U.S. at 445 n.29.

207. Nat'1 R.R. Passenger Corp. v. Boston \& Me. Corp., 503 U.S. 407, 417 (1992).

208. NationsBank of N.C., N.A. v. Variable Annuity Life Ins. Co., 513 U.S. 251, 257 (1995). 
agency that produces consequences contrary to congressional intent can hardly be deemed a "permissible construction."

Impact Aid was originally enacted to ensure that students educated in areas impacted by federal lands are not penalized by the inability of their school district to levy taxes against those lands, ${ }^{209}$ and to provide support for the equalization efforts of the states. The statute was amended in 1974 with the intent of avoiding duplicative compensation to LEAs impacted by federal lands. ${ }^{210}$ The statute accomplishes all three goals by providing aid to LEAs while also allowing states to consider the aid received by LEAs if the Secretary considers that state equalized. ${ }^{211}$

True to its original purpose, Impact Aid goes to many school districts on or near American Indian reservations. The Aid often comprises significant portions of these school districts' budgets, ${ }^{212}$ and helps the districts address unique learning challenges faced by Native American schoolchildren. When cuts to Impact Aid are made, school districts on or near tribal lands often suffer the most, prompting Senator Tom Daschle to note that cuts to Impact Aid make it "harder for Native Americans to receive [the] high quality education they deserve." ${ }^{213}$ In the aftermath of Aid cuts, school districts like the Lapwai School District in Idaho, located within the Nez Perce Indian Reservation, have to choose between paying for extra academic programs that help students excel academically and making desperately needed capital improvements. ${ }^{214}$

Zuni Public School District and Gallup-McKinley Public School District are similarly compromised. Both school districts have felt the impact of insufficient funding for education, and argue that allowing New Mexico to reduce their equalization distribution by the amount

209. 20 U.S.C. $\S 7701$ (2000).

210. See U.S. Gen. AcCouting OfFICE, supra note 70, at 16 (noting the purpose of the exception was to "prevent [I]mpact [A]id from hindering states' equalization efforts and [to prevent] duplicative compensation [to] school districts affected by federal activity (once by the federal government through impact aid and a second time by the state's equalization program)").

211. 20 U.S.C. $\$ 7709$ (b)(1).

212. See Bryan Jernigan, Lapwai School District Depends on Impact Aid, InDIAN CounTRY TODAY (Oneida, N.Y.) Feb. 19, 2003, at D1, available at http://www.indiancountry.com/ content.cfm?id=1045754055 (In 2003, Impact Aid accounted for twenty-nine percent of Lapwai's total operating budget, leading Superintendent Harold Otto to note that "[w]ithout Impact Aid, our school district would shut down").

213. David Melmer, South Dakota Schools Lose Due to Cuts in Impact Aid, InDIAn CounTRY TODAY (Oneida, N.Y.) Mar. 19, 2003, at B1, available at http://www.indiancountry.com/ content.cfm?id=1048084252.

214. See Jernigan, supra note 212 (explaining that despite the success of reading programs that have brought significant percentages of students to grade level, the district must consider foregoing the programs to instead address building ventilation and mold problems that are causing illness in teachers and students). 
received in Impact $\mathrm{Aid}^{215}$ has led to a "shortfall of support for some of the neediest public school students in the state." 216 Petitioners emphasize that educating Native American children in rural, isolated environments entails addressing special problems that stem from poverty, language differences and cultural differences. ${ }^{217}$ "Just 28[\%] of Native American ninth-graders in New Mexico are reading at grade level," compared to "35[\%] for the state's Hispanic students, and 62[\%] for [the state's] Anglo students." 218 "More than 80[\%] of students in the GallupMcKinley district are Native American, and all students in the Zuni district are Native American." ${ }^{219}$ Tutoring and other academic programs for which Impact Aid pays would help close the performance gap for these students. ${ }^{220}$

Moreover, the districts' compromised taxing capacity has impeded their ability to fund capital improvements. New Mexico's capital outlay funding system, which has previously been declared unconstitutional due to a failure to abide by the state constitution's "uniformity clause," 221 is continually being monitored by a New Mexico District Court. Through the Public School Capital Outlay Act, the state evaluates the adequacy of facilities in each district and provides funding for facilities based upon relative need. ${ }^{222}$ Wealthier districts with higher bonding and taxing capacities, however, are also able to approve additional local property levies, and issue general obligation bonds to independently raise additional resources for capital improvements. In addition, districts with political clout may be able to obtain direct legislative appropriations for capital outlay projects, as was the case in May of 2006 when Albuquerque's West Side received its share of an extra $\$ 90$ million for capital projects in high-growth areas. ${ }^{223}$

215. SCH. Budget \& Fin. ANAlysis BuREAU, supra note 47, at 11 ("The state takes credit for $75[\%]$ of all Impact Aid revenues flowing to local districts... when calculating the state equalization guarantee."). B1.

216. Gabriela C. Guzman, Civil War Over School Funding, AlbuQuerque J., Jan. 7, 2007, at

217. Petition for Writ of Certiorari, supra note 94, at 18.

218. Guzman, supra note 216.

219. Id.

220. Id.

221. National Access Network Webpage, New Mexico: Historical Background, April 7, 2006, http://www.schoolfunding.info/states/nm/lit_nm.php3 (last visited Oct. 6, 2007) (citing Zuni School District v. State, CV-98-14-II (Dist. Ct. McKinley County, Oct. 14, 1999)).

222. SCH. BUdGet \& Fin. ANALYSIS BUREAU, supra note 47 , at 8 .

223. National Access Network Webpage, New Mexico Plaintiffs Claim State is Backtracking on Capital Funding, May 11, 2006, http://www.schoolfunding.info/news/litigation/5-11-06nmfacilities review.php3 (last visited Oct. 6, 2007). 
Unfortunately, these additional options are not available to poorer districts with impaired taxing capabilities. Accordingly, facilities in low property-wealth districts like Zuni and Gallup-McKinley have deteriorated. $^{224}$ In the Gallup-McKinley school district, construction delays have forced middle schools to operate out of portable classrooms with no running water and inadequate heating. ${ }^{225}$ Both districts need the additional resources provided by Impact Aid to repair and replace dilapidated school buildings. ${ }^{226}$

Additional funding is also needed to provide housing and salary incentives for teachers in the two districts. ${ }^{227}$ In Zuni, where districtprovided housing is often the only option for school employees who are not tribal members, teachers make do with trailer homes. ${ }^{228}$ Educators living in the trailers have had to deal with raw sewage backing up into their homes, or deteriorated construction which in one trailer led to a toilet literally falling through the floor. ${ }^{22}$ To compound hiring problems, New Mexico's education funding system makes additional payments to those districts that employ advanced-degree teachers. ${ }^{230}$ But in districts like Zuni or Gallup-McKinley that depend on national programs like Teach for America to recruit recent college graduates to teach, rural isolation and poor conditions compromise the districts' ability to hire and retain highly-qualified teachers. ${ }^{231}$ The result is that wealthier and more desirable districts easily retain their teachers and receive additional funding to support their higher salaries, while the impacted districts do not receive additional funding, but nevertheless have to pay higher salaries to attract instructors. Zuni Superintendent Kaye Peery notes that additional funding is desperately needed to attract and retain highlyqualified teachers for the rural district. ${ }^{232}$

224. National Access Network Webpage, New Mexico Historical Background, Apr. 7, 2006, http://www.schoolfunding.info/states/nm/lit_nm.php3 (last visited Oct. 6, 2007).

225. Guzman, supra note 216.

226. See id. (reporting that the "districts say they need the extra money-desperately").

227. Id.

228. Id.

229. Id.

230. N.M. Stat. AnN. § 22-8-24 (West 2003 \& West Supp. 2006); SCH. Budget \& Fin. ANALYSIS BUREAU, supra note 47, at 5 (noting that calculations of program cost for each district consider a district's "training and experience index"); BALL \& GARCIA, supra note 50, at 5-6 (explaining how New Mexico's "training and experience index" is determined and applied to calculate program costs). See also Petition for Writ of Certiorari, supra note 94, at 18.

231. Guzman, supra note at 216.

232. See id. ("'How can a school district recruit highly qualified teachers under conditions like these?' Peery asked."). 
Accordingly, the Secretary's formula may allow New Mexico to ignore not a problem of horizontal equity, but one of vertical equity and adequacy. New Mexico's funding formula does result in per-pupil expenditures that are equalized on paper. For the 2000 fiscal year, a perpupil revenue of $\$ 3320$ placed Zuni at thirteenth in a ranking of districts throughout the state. ${ }^{233}$ Although the first ranked Mosquero district still had approximately $\$ 3200$ more in per-pupil revenues, Zuni’s per-pupil expenditure for that year was just above the mean of $\$ 3192.08 .{ }^{234}$ Nevertheless, the unique needs of impacted districts populated by Native American students warrant additional funding in order to successfully provide adequate educations that result in academic achievement.

Although New Mexico's funding formula does use cost differentials, the hardships suffered by both districts suggest that the formula fails to account for the districts' significant academic, recruiting, and facilities challenges. The funding formula does not, for example, account for the 330 housing units that Gallup-McKinley must provide for its teachers. ${ }^{235}$ As one Zuni school board member said, "educating a student here is not the same as in Albuquerque. It takes a little bit more."236 If both the Zuni and Gallup-McKinley districts had received Impact Aid for the 2005-06 school year without a corresponding decrease in their state equalization distributions, the districts would have received an additional \$4.6 million and \$15.6 million, respectively. ${ }^{237}$ This would have allowed them to implement special academic support programs and make needed capital improvements. This additional funding would not be the "duplicative" compensation that Congress sought to prevent, but the supplemental funding needed by the districts to educate its students in a way that is comparable to other districts in the state with fewer special needs. Moreover, as admitted by New Mexico Education Secretary Veronica Garcia, the $\$ 50$ million loss incurred by the state due to the inability to take credit for Impact Aid payments is insignificant, ${ }^{238}$

233. Brief for the Petitioners, supra note 58, at 19-20.

234. Id. at 19-21.

235. Ernest Mackel et al., Guest Opinion Column, Blame State, Not Schools, for Funding Inequities, AlBuQuerQue J., Feb. 2, 2007, at A13 (containing response of the Zuni, GallupMcKinley, and Grants-Cibola school board presidents to New Mexico Secretary of Education Veronica Garcia's statement that New Mexico distributes education resources in an equitable manner).

236. Guzman, supra note 216.

237. See id. (stating that the state took credit for $\$ 4.6$ million of the $\$ 8.2$ million in federal Impact Aid given to Zuni, and \$15.6 million of the \$27.7 million given to Gallup-McKinley).

238. Reply Brief for the Petitioners, at 16-17, Zuni Pub. Sch. Dist. No. 89 v. U.S. Dep't of Educ., 127 S. Ct. 1534 (2007) (No. 05-1508), 2006 WL 3854045 (noting that Impact Aid payments amount to only $2.6 \%$ of New Mexico's educational budget). 
particularly when compared to New Mexico's fiscal strength, ${ }^{239}$ and the $\$ 2.2$ billion the state spends annually on public education. ${ }^{240}$

As has been illustrated, state aid which supplements a district's shallow tax base may fall far short of the amount needed to educate underachieving, isolated students in a district with deteriorating facilities. Accordingly, the Department of Education cannot use horizontal equity measures alone to accurately assess whether a state's funding system provides enough to meet the fair cost of adequately educating students with special needs. Yet, this is precisely what the Department of Education's equalization formula does. Technically referred to as a "restricted range ratio," 241 the Department's practice of comparing revenue at the ninety-fifth and fifth percentiles assesses the degree of horizontal equity. This is true whether percentile cut-offs are based on the number of LEAs or student population. As such, the formula fails to account for vertical equity or adequacy in New Mexico. ${ }^{242}$

Arguably, the Secretary has little control over the equalization formula preferred by Congress. Congressional language mandates the restricted range ratio, and the Secretary cannot independently replace the ratio with a formula that takes better account of vertical equity. The Secretary can, however, consider the consequences of both versions of the restricted range ratio in light of congressional intent. Without the additional aid, Zuni and Gallup-McKinley are forced to address the very situation Congress intended to prevent: an inability to effectively address achievement gaps, maintain adequate facilities, or attract qualified teachers because of the presence of tax-exempt federal lands in the school district. This consequence suggests that use of the harder-to-meet equalization formula, which bases percentile cut-offs on the number of

239. See Press Release, Office of the Governor, State of New Mexico, Governor Richardson Releases Statement on New Revenue Estimates (Oct. 23, 2006), available at http:// www.governor.state.nm.us/press/2006/oct/102306_02.pdf (announcing an additional \$576 million in recurring revenues will be available for the 2007 legislative session, \$913 million is estimated to be available for capital outlay projects, and $\$ 142$ million is estimated to be set aside for efforts to modernize schools across the State).

240. See Guzman, supra note 216 (discussing interview with New Mexico Education Secretary Veronica Garcia, in which she expressed that the issue is not the money but the questioning of "the philosophical foundation of [New Mexico's] funding formula").

241. See AleXAnder \& SALMON, supra note 8, at 235-36 (explaining that the federal range ratio used by the federal government in the Impact Aid program is mathematically equivalent to the restricted range ratio)

242. See, e.g., The National Association of Federally Impacted Schools, High Court to Rule on Equalization, Jan.-Feb., 2007, at 8, available at http://www.nafisdc.org/images/Jan-Feb\%2007\% 20Impact\%20Newsletter.pdf ("[T] that all children within a state receive a [sic] 'adequate education,' but rather only recognizes a form of spending per pupil that, although equalizes per-pupil spending as interpreted by the regulations, makes no attempt to insure students within a state are receiving an adequate education."). 
LEAs, might have been warranted. Such a choice is even more appropriate in light of plain statutory language that seems to require it. The constraining nature of Chevron review, however, led to the Court's failure to either consider the consequences of the Secretary's interpretation, or evaluate how those consequences informed the Secretary's decision. Accordingly, the Court was unable to accurately determine whether the Secretary's interpretation and ensuing choice of formula were in accordance with congressional intent.

\section{B. Agency Expertise and the Department of Education}

Ensuring the quality of primary and secondary education is a job historically left to state and local governments. Congress established the Department of Education in 1979 as a cabinet-level agency through the Department of Education Organization Act (DEOA) ${ }^{243}$ Although one of the Department's seven stated purposes is to "supplement and complement the efforts of States" in improving the quality of education, ${ }^{244}$ the Act specifically notes that the establishment of the Department did not "increase the authority of the Federal Government over education or diminish the responsibility for education which is reserved to the States and the local school systems." ${ }^{245}$ In addition, neither the Secretary nor the Department of Education can exercise any "direction, supervision, or control over the curriculum [or] program of instruction ... of any educational institution, school, or school system, except to the extent authorized by law." 246

The emphasis on local control of education has similarly been reinforced by the Supreme Court. In Milliken v. Bradley, ${ }^{247}$ the Court emphasized that "[n]o single tradition in public education is more deeply rooted than local control over the operation of schools." 248 Likewise, the Court in United States v. Lopez ${ }^{249}$ noted that although "Congress has authority under the Commerce Clause to regulate... commercial activities that ... affect the educational process," that authority "does not include the authority to regulate each and every aspect of local

\footnotetext{
243. Department of Education Organization Act, Pub. L. No. 96-88, § 102, 93 Stat. 670 (1979) (codified as amended at 20 U.S.C. $§ 3402(2000)$ ).

244. 20 U.S.C. $\$ 3402(2)(2000)$

245. Id. § 3403(a).

246. Id. § 3403(b).

247. 418 U.S. 717 (1974).

248. Id. at 741 .

249. 514 U.S. 549 (1995).
} 
schools." 250 As such, schools are controlled locally and the majority of decisions that affect hiring, curriculum and funding are made by individual school districts. ${ }^{251}$

Accordingly, the Department interacts at an arm's length distance with local education agencies. ${ }^{252}$ Even the No Child Left Behind Act of 2001 (NCLB), ${ }^{253}$ a law that represented a dramatic departure from the federal government's traditional hands-off approach to state and local education, ${ }^{254}$ evinces an effort on the part of federal lawmakers to avoid taking too heavy a hand in public school operations. NCLB does not impose any uniform federal student assessment measure upon the states, opting instead to require individual states to develop assessments and submit them for approval to the Department of Education. ${ }^{255}$

This is not to say, however, that the federal government has played absolutely no role in ensuring quality education. To the contrary, the federal government administers hundreds of educational aid programs, including Title I of the Elementary and Secondary Education Act ${ }^{256}$ "the largest single federal investment in schooling."257 Historically, the federal government has also supported the equalization of educational opportunities for students and has played a major policy role in the education of "insular and discrete" 258 student populations. ${ }^{259}$

250. Id. at 566 .

251. Molly S. McUsic, The Law's Role in the Distribution of Education: The Promises and Pitfalls of School Finance Litigation, in LAW AND SCHOOL REFORM, 88, 93 (Jay P. Heubert ed., 1999).

252. Judith A. Winston, Achieving Excellence and Equal Opportunity in Education: No Conflict of Laws, 53 Admin. L. REV. 997, 1007 (2001). See also Michael Heise, The Political Economy of Education Federalism, 56 EMORY L.J. 125, 134 (2006) (noting that the federal government has had little to do with most of the nation's primary and secondary schools).

253. No Child Left Behind Act of 2001, Pub. L. No. 107-110, 115 Stat. 1425.

254. Historically, the federal government has preferred to suggest, and encourage states to adopt, voluntary reform goals. In contrast, NCLB is the first federal education program to impose requirements that students progress to a measure of proficiency within a certain time period.

255. Heise, supra note 252, at 141. The one aspect of the Act which imposes a test- the requirement for participation in the National Assessment of Education Progress (NAEP) testing program - does not trigger consequences for a state or district's failure to participate. Id.

256. The Department of Education has, however, been criticized for its failure to issue guidelines governing the use of aid program funds, the lack of which has led to abuse. See McUsic, supra note 251, at 94 (discussing how lack of guidelines has led to disparate treatment of schools who need the funding the most).

257. Inst. of Educ. Sciences, Nat. Ctr. for Educ. Statistics, http://nces.ed.gov/fastfacts/display .asp?id=158 (last visited Sept. 12, 2007).

258. Heise, supra note 252, at 134.

259. See, e.g., OfFICE Of COMMC'NS \& OUTREACH, U.S. DeP'T Of EduC., Guide to U.S. DeP'T OF EDUC. PROGRAMS 56 (2006), available at http://www.ed.gov/programs/gtep/gtep.pdf (referencing Elementary and Secondary Education Act of 1965, a federal program that provides financial assistance to local education agencies and schools "with high numbers or high percentages of poor children to ... ensure that all children meet challenging state academic standards"); $i d$. at 
Furthermore, the Department of Education serves as a "clearinghouse" for "ideas, facts and figures" related to the improvement of education, ${ }^{260}$ monitors local education agencies, ${ }^{261}$ and enforces federal antidiscrimination laws in federally funded educational institutions through the Department's Office of Civil Rights. ${ }^{262}$

The Department of Education has also played a role in ensuring quality education for Native American students in particular. The Department maintains an Office of Indian Education, the mission of which "is to support the efforts of local educational agencies, Indian tribes and organizations, postsecondary institutions, and other entities to meet the unique educational and culturally related academic needs of American Indians... so that these students can achieve to the same challenging state standards as all students." ${ }^{263}$ Moreover, the Department is familiar with the unique challenges faced by children living on Indian reservations, and has noted that "Impact Aid is often an extremely important source of revenue for school districts that serve children living on Indian reservations and other Indian lands, because these districts frequently have a very small local property tax base from which to raise revenue for schools." 264

Accordingly, the Department possesses considerable expertise that should have been brought to bear in considering the consequences of its application of the federal equalization formula. In particular, the Department

252 (referencing Individuals with Disabilities Education Act (IDEA), a federal program that provides grants to states to assist with the "costs of providing special education and related services to children with disabilities"); id. at 227 (referencing Even Start, a federal grant program which supports local family literacy programs "that integrate early childhood education, adult literacy ... parenting education, and interactive parent and child literacy activities for low-income families").

260. Richard W. Riley, The Role of the Federal Government in Education-Supporting a National Desire for Support for State and Local Education, 17 ST. LouIS U. PUB. L. REV. 29, 36 (1997).

261. School accountability as maintained by the Department of Education, however, differs from accountability provided by other regulatory agencies. Paul Weckstein, co-director of the Center for Law and Education, has written about the dearth of accountability regarding federal programs that regulate local schools in the area of standards-based reform. Most teachers are not familiar with the substantive provisions of the federal programs that regulate their schools, and non-compliance is not considered outside the norm. In contrast, when FDA issues rules regarding medication, the norm is that doctors will become immediately aware of those rules, that there will be a high degree of compliance, and that the agency will be ready to take remedial action should it discover regulations have not been followed. Paul Weckstein, School Reform and Enforceable Rights to Quality Education, in LAW AND SCHOOL REFORM, 306, 319 (Jay P. Heubert ed., 1999).

262. Riley, supra note 260, at 39.

263. ED.gov, Ensuring No American Indian and Alaska Native Child is Left Behind, http:// www.ed.gov/about/offices/list/oese/oie/index.html (last visited Sept. 15, 2007).

264. OfFice of Elementary and SeCONDARy Educ., U.S. Dep'T of EduC., Indian COMMUNITY PARTICIPATION IN THE IMPACT AID PROGRAM: SPECIAL IMPACT Aid PROVISIONS FOR LOCAL EDUCATION AgENCIES THAT Claim CHILDREN RESIDING ON INDIAN LANDS 5 (2001), available at $\mathrm{http}: / / \mathrm{www} . e d . g o v /$ programs/8003/icpbooklet.pdf. 
should understand the methodological flaws inherent in the formula it uses to determine equalization among the states. The "restricted range ratio" ${ }^{, 265}$ compares revenue at the ninety-fifth and fifth percentiles to assess the degree of horizontal equity in a state school system. The ratio, however, only measures two extreme points in a data set. As such, the restricted range ratio is a poor indicator for assessing the degree of equity in an entire education system, ${ }^{266}$ and fails to provide information concerning the entire distribution of per-pupil revenues. As a result, the formula is limited in its ability to detect inequity in a school finance system, ${ }^{267}$ and fails to consider the amount of vertical equity needed to provide adequate education for all students.

Although the Secretary cannot mandate the use of an alternate formula, the Secretary can use its understanding of the methodological flaws in the formulas, and the context of equalization in New Mexico, to make a decision about which formula to use. The Secretary is aware that once deemed equalized, a state is likely to reduce its funding to impacted districts by the amount of Aid received by those districts. The Department must also be aware that it is precisely those districts with compromised taxing capabilities that are most likely to be affected when a state exercises its option to offset Impact Aid. Moreover, it is foreseeable that impacted districts populated by Native American students are more likely to have special needs that warrant additional funding to ensure adequacy. In light of the context of equalization in New Mexico, and the knowledge that the formula which bases percentile cut-offs on student population is particularly problematic in New Mexico, the Secretary should have considered using the equalization formula which was harder for New Mexico to meet. The easier standard made it possible for New Mexico to qualify as an equalized state, but resulted in denying additional funding to those students who need it the most.

Of course, it is possible that the Department considered the consequences of applying both versions of the equalization formula, and nevertheless decided that its formula was the best option. Neither submitted briefs nor transcripts of oral argument, however, illustrate that the Department considered the actual consequences of its formula on

265. See AlexAnder \& SAlmon, supra note 8, at 235-36 (explaining that the federal range ratio used by the federal government in the Impact Aid program is mathematically equivalent to the restricted range ratio).

266. ODDEN \& PICUS, supra note 14, at 61.

267. Robert Berne \& LeANNA Stiefel, The MEASurement of Equity in School FinANCE 69 (1984) (illustrating that the inability of the federal range ratio to measure per-pupil revenues for all students results in a failure to detect an unequal proportional increase in per-pupil revenue). 
impacted districts in New Mexico. There is also no indication that the Department evaluated whether its formula deemed New Mexico equalized at the expense of the population that Congress sought to protect through the enactment of Impact Aid.

Furthermore, although determining disparity among school districts is inherently an exercise in statistics, the Department completely failed to consider statistical analysis issues in its interpretation. In his opinion, Justice Breyer took comfort in the fact that the Court's interpretation of the Impact Aid Statute, which mirrored the Department's interpretation, had not been challenged by any statistician. ${ }^{268}$ Justice Breyer's comfort, however, is fleeting. In his article, A Sixty Million Dollar Statistical Issue in the Interpretation and Calculation of a Measure of Relative Disparity, Professor Joseph L. Gastwirth of the George Washington University Department of Statistics examined the Department's interpretation and found it statistically flawed. Contrary to the Court's assertion that there are multiple ways to read the Impact Aid statute, Professor Gastwirth argues that the statistically straightforward interpretation of the statute is the interpretation advocated for by Petitioners. ${ }^{269}$ As Professor Gastwirth explains:

[T] he statute specifies a population of LEAs, the individual units, and the characteristic of interest is the AE [average per-pupil expenditure] of the LEA. By arranging the LEAs in increasing order of their expenditures, we obtain the distribution of the AEs in the universe of LEAs in the state .... The disparity calculation is made by first taking the difference ... between the 95th percentile and the fifth percentile of the AEs of the LEAs. The 95th and fifth percentiles are used in the calculation as the statute clearly states that LEAs with expenditures (or revenues) "above" the 95th or 'below' the fifth percentile should be disregarded. ${ }^{270}$

To support this assertion, Professor Gastwirth conducted an informal survey of twenty-seven professional statisticians. Among all twentyseven respondents, only two interpreted the Impact Aid statute in the same way as the Department of Education, and then only as a possible alternative interpretation assuming the number of pupils would be reported. ${ }^{271}$ The overwhelming majority of statisticians surveyed

268. Zuni Pub. Sch. Dist. No. 89 v. U.S. Dep't of Educ., 127 S. Ct. 1534, 1546 (2007).

269. J.L. Gastwirth, A Sixty Million Dollar Statistical Issue Arising in the Interpretation and Calculation of a Measure of Relative Disparity: Zuni Public School District 89 v. U.S. Department of Education, 5 LAW, PROBABILITY, \& RISK 33, 39 (2006).

270. Id. at 40 .

271. Id. at 45 . 
understood the Impact Aid statute in the same manner advocated for by Zuni and Gallup-McKinley. ${ }^{272}$

In addition to highlighting that the Department's interpretation of the Impact Aid statute is out of step with the understanding of most professional statisticians, Professor Gastwirth also identified statistical infirmities with the Department's interpretation. Specifically, if one or both of the LEAs at the high and low end of the distribution contained at least five percent of the population, those LEAs would be the fifth or ninety-fifth percentile in the distribution, and would not be eliminated from disparity determinations. ${ }^{273}$ Thus, despite the Department's desire to eliminate outliers, the Department's own interpretation can nevertheless fail to remove LEAs with anomalous characteristics. ${ }^{274}$ Moreover, the Department incorrectly asserts that eliminating LEAs, without first considering pupil population, will necessarily disadvantage states with a small number of large school districts. ${ }^{275}$ Such a disadvantage will only occur when there are at least twenty districts in a state, many of which must also be small. ${ }^{276}$

Despite the presence of these statistical issues, the Department of Education neither used a statistician as an expert witness during the lower court proceedings, nor gave the Supreme Court any indication that it consulted statisticians for its interpretation of the Impact Aid statute. As perhaps an indication of the Department's failure to carefully work with the data it was given, Professor Gastwirth discovered an arithmetic error in the Department's analysis. ${ }^{277}$

The Supreme Court has stated that the weight afforded administrative agencies "will depend upon the thoroughness evident in its consideration, [and] the validity of its reasoning." 278 The Court has also stated that deference will depend on the "related expertise of the

272. See id. at 44 (stating that twenty-five of the responses to the two versions of the study corresponded with the plaintiff's calculation and interpretation).

273. Id. at 53 .

274. Id.

275. Id. at $35-36,53$

276. Id. Professor Gastwirth also draws attention to the methodological infirmities of the Impact Aid formula which apply to both Petitioners' and Respondents' interpretation of the statute. For example, the formula is based on an averaging process that reduces variation in the data, potentially masking a larger degree of variability in per-school inequality. $I d$. at 46 . In addition, the practice of eliminating LEAs at the fifth and ninety-fifth percentiles is not statistically sound for sets of data like per-pupil expenditure among LEAs, which are not "normal" or distributed symmetrically around a central value. Rather, the elimination of the fifth and ninety-fifth percentiles are more appropriate for data sets that are normal or distributed in a bell-shaped curve. Id. at 48-49.

277. Id. at 55

278. U.S. v. Mead Corp., 533 U.S. 218, 219 (2001) (quoting Skidmore v. Swift \& Co., 323 U.S. $134,140(1944))$. 
Agency, the importance of the question to administration of the statute... and the careful consideration the Agency has given the question over a long period of time." 279 Here, the Department failed to consider the consequences of using a restricted range ratio, or to consult a statistician even though the question at issue involved statistics. Moreover, the Department provided unpersuasive justifications for its interpretation, and even committed arithmetic errors when manipulating the relevant data. These actions suggest careless and superficial consideration of issues that were central to properly assessing disparity in a state educational funding system. Accordingly, the Department's interpretation should have been given very little weight, if any at all. The doctrinal confines of Chevron review, however, constrained the Court's review of agency interpretation. The application of Chevron review did not encourage the Department to illustrate the extent to which agency expertise was brought to bear in the Department's decision. Nor did Chevron review encourage the Court to inquire. If the Court had inquired, it would have been clear that there was little agency expertise on the Department's part to actually consider.

\section{A Solution: Resurrecting “Hard-Look” Review}

The failure to consider the practical implications of the Secretary's interpretation, to determine whether congressional intent is being met, or to ensure whether the Department of Education spent sufficient time considering its interpretation of the Impact Aid statute is particularly problematic in light of the highly deferential second prong of Chevron review $^{280}$ and the unlikelihood that once there, the Court will find the Secretary's interpretation impermissible. ${ }^{281}$ Automatic deference without consideration of the concerns invoked by the case led to a failure to

279. Barnhart v. Walton, 535 U.S. 212, 222 (2002).

280. See Seidenfeld, supra note 202, at 96 ("Regardless of whether a reviewing court is deferential or active, once it reaches step two it rarely reverses an agency interpretation as unreasonable.”); Gary Lawson, Outcome, Procedure and Process: Agency Duties of Explanation for Legal Conclusions, 48 RUTGERS L. REV. 313, 314 (1996) ("Observers of modern administrative law know that most of the action in Chevron cases is focused on step one. If the reviewing court finds the relevant statute ambiguous, the agency's interpretation is almost always upheld at step two, with little discussion by the court."); Levin, supra note 117, at 1261 (finding that "in the thirteen years since Chevron, the Court has never once struck down an agency's interpretation by relying squarely on the second Chevron step").

281. See Levin, supra note 117, at 1270 (noting that generally, the Court grants certiorari in order to resolve clear-cut legal issues, and leaves to the lower courts responsibility for evaluating the manner in which agencies apply legal principles to fact situations. Accordingly, the Court is unlikely to take a case with the expectation of holding that the agency's interpretation passes step one of Chevron review but fails step two). 
apply Impact Aid in its intended manner, to the detriment of New Mexico schoolchildren.

The Court and the parties before it, however, could have been released from the constraints of traditional Chevron review and freed to consider these concerns if the Department was required to justify the validity of its statutory interpretation. By requiring the agency to address the policy implications of its interpretation, to illustrate that its interpretation would not result in consequences that clash with congressional intent, and to prove that its decision-making process was thorough, the Court could have avoided rubber-stamping an agency decision that warranted a more rigorous review.

Insisting that agencies justify their reasoning and policy decisions to a court is hardly a new idea. When reviewing informal agency rulemaking under the Administrative Procedure Act's (APA) "arbitrary and capricious" standard, ${ }^{282}$ courts have invoked a standard of review that extends deference to the agency but also mandates a "substantial inquiry" into the facts. ${ }^{283}$ Although a court may not substitute its judgment for that of the agency, and the agency's decision is entitled to a "presumption of regularity," ${ }^{284}$ a substantial inquiry into whether the decision was made based on consideration of all relevant factors is still required. ${ }^{285}$ In elaborating on this standard, the D.C. Circuit has written that close scrutiny of evidence, particularly in complex matters, is meant to educate the court, as the court must understand "enough about the problem confronting the agency to comprehend the meaning of the evidence relied upon and the evidence discarded; the questions addressed by the agency and those bypassed; the choices open to the agency and those made." 286 In this way, a court can determine whether the agency decision was "rational and based on consideration of the relevant factors." 287

282. 5 U.S.C. $\S 706(2)(A)(2000)$.

283. Citizens to Preserve Overton Park, Inc. v. Volpe, 401 U.S. 402, 415-16 (1971), overruled on other grounds by Califano v. Sanders, 430 U.S. 99, 105 (1977). In determining whether the Secretary made a choice that was arbitrary, capricious, or an abuse of discretion, although the Secretary's decision was entitled to a presumption of regularity, the applicable standards of $\S 706$ required the Court to engage in a substantial inquiry. Id. at 415. To make a decision, the Court had to make a searching and careful consideration of whether the decision was based on a consideration of all relevant factors. Id. at 416 . Nevertheless, the Court is not permitted to substitute its judgment for that of the agency. Id.

284. Id. at 415-16.

285. Id.

286. Ethyl Corp. v. EPA, 541 F.2d 1, 36 (D.C. Cir. 1976).

287. Id. at 36 . 
The application of arbitrary and capricious review is not without challenge, and has been subject to critiques that it contributes to the "ossification" of informal rulemaking. ${ }^{288}$ According to this critique, arbitrary and capricious review, particularly as performed in the D.C. Circuit, is both too intensive and too costly. ${ }^{289}$ To pass the arbitrary and capricious review to which informal rules may be subject under the APA, an agency must explain its reasoning in excruciating detail, respond to every comment, and anticipate which issues will be of most concern to a reviewing court. ${ }^{290}$ Moreover, even when agencies take these steps, there is only a $50 \%$ chance their process will pass review. ${ }^{291}$ Faced with this daunting task, agencies have become reluctant to use the informal rulemaking process, despite the advantages of prior notice and public participation that informal rulemaking provides. ${ }^{292}$

In response to the critiques, scholars and judges alike argue that the effects of arbitrary and capricious review do not warrant any changes in standard. Judge Wald has written that when applying arbitrary and capricious review, courts merely seek "to ensure that the agencies do what Congress has told them to do and that they exercise discretionary power in a reasonable fashion."293 Additionally, Professor William S. Jordan has found that agency regulatory programs have continued despite failing arbitrary and capricious challenges, and that when rules were remanded under arbitrary and capricious review, agencies tended to recover quickly. ${ }^{294}$

288. See William S. Jordan III, Ossification Revisited: Does Arbitrary and Capricious Review Significantly Interfere with Agency Ability to Achieve Regulatory Goals Through Informal Rulemaking?, 94 Nw. U. L. REV. 393, 393-94 (2000) (“"T] he 'arbitrary, capricious, or abuse of discretion' standard has been a major culprit in the 'ossification of informal rulemaking."'); Thomas O. McGarity, Some Thoughts on “Deossifying” the Rulemaking Process, 41 DuKE L.J. 1385, 1419 (1992) ("The predictable result of stringent 'hard look' judicial review of complex rulemaking is ossification."); Thomas O. McGarity, The Courts and the Ossification of Rulemaking: A Response to Professor Seidenfeld, 75 TEX. L. REV. 525, 528-29 (1997) ("[T]he hard look doctrine caused the rulemaking process to 'ossify' to a disturbing degree."); Richard J. Pierce, Jr., The APA and Regulatory Reform, 10 ADMIN. L.J. 81, 82 (1996) ("There is a broad consensus among scholars that ossification of the rulemaking process is the largest single implementation problem today.").

289. See, e.g., JORDAN, supra note 288, at 400 ("Hard look review is said to be too intensive, too costly, and ineffective in assuring reasoned decisionmaking.").

290. Id.

291. PIERCE, supra note 288 , at 83.

292. JORDAN, supra note 288 , at 393 .

293. Patricia M. Wald, Judicial Review in the Time of Cholera, 49 ADMIN. L.J. REV. 659, 662 (1997).

294. JORDAN, supra note 288 , at 393-94. 
Despite the on-going debate, "hard-look" 295 arbitrary and capricious review has long been thought to overlap substantially with the second step of Chevron review. Judge Laurence Silberman, a D.C. Circuit Court judge, first noted in 1988 that the second step of Chevron is "not all that different analytically from the APA's arbitrary and capricious review," and that both require a court to ask whether the agency considered and weighed the factors that Congress envisioned it would. ${ }^{296}$ Since then, judges have noted the places in which the two doctrines converge and diverge. The D.C. Circuit, the tribunal that hears a significant number of challenges to agency action, ${ }^{297}$ has issued a line of opinions that have highlighted the distinction between the two doctrines, including Arent $v$. Shalala. ${ }^{298}$ Arent noted that although Chevron review and arbitrary and capricious review "overlap at the margins," the two doctrines ask different questions: step two of Chevron review asks "whether an agency has authority to act under a statute," while arbitrary and capricious review asks whether the discharge of that authority was reasonable."299 Similarly, Texas Office of Public Utility Counsel v. FCC, ${ }^{300}$ a Fifth Circuit case, has also drawn the distinction, noting that "“arbitrary and capricious' review under the APA differs from Chevron step two review because it focuses on the reasonability of the agency's decision-making processes rather than on the reasonability of its interpretation." 301

Scholars have also analyzed the extent to which the two review schemas overlap. Finding that Chevron deference is under-girded by a flawed pluralistic democracy model, Professor Mark Seidenfeld has argued that a more satisfactory "deliberative democracy" requires a revamping of Chevron review. ${ }^{302}$ In this new version of Chevron the

295. The D.C. Circuit has adopted this test for the review of informal policymaking under the arbitrary and capricious standard. See Sierra Club v. Costle, 657 F.2d 298, 410 (D.C. Cir. 1981) ("We have read the record with as hard a look as mortal judges can probably give."); Ethyl Corp. v. EPA, 541 F.2d 1, 33-36 (D.C. Cir. 1975) (noting that the court "must engage in a "substantial inquiry' into the facts, one that is 'searching and careful'").

296. Laurence H. Silberman, Chevron-The Intersection of Law \& Policy, 58 GeO. WASH. L. Rev. 821, 827-28 (1990) (citing Gen. Am. Transp. Corp. v. ICC, 872 F.2d 1048, 1053 (D.C. Cir. 1989) (majority opinion of Silberman, J.)).

297. Levin, supra note 117, at 1256 (noting that the D.C. Circuit is the forum with the "greatest frontline responsibility for judicial review of agency action").

298. 70 F.3d 610 (D.C. Cir. 1995)

299. Id. at $615-16$.

300. 183 F.3d 393 (5th Cir. 1999).

301. Id. at 410 .

302. Seidenfeld, supra note 202, at 83. Professor Seidenfeld advocates for a modification to Chevron review that fosters deliberative democracy. Through review of statutory interpretation courts have an opportunity to interact with agencies and ensure agencies both act deliberatively and remain politically accountable. Adding a policy emphasis to the second step of Chevron review ensures that agencies have avoided excessive special interest influence. Id. 
emphasis would be on the second step instead of the first, and would "[force] agencies to explain why their interpretations are good policy in light of the purposes and concerns underlying the statutory scheme" in question. $^{303}$ Professor Seidenfeld likens this revamped second prong to the D.C. Circuit's arbitrary and capricious "hard look" test, and envisions encouraging courts to require "agencies to identify those concerns that the statute addresses and explain how the agency's interpretation took those concerns into account." ${ }^{304}$ Moreover, the agency would be forced to explain "why it emphasized certain interests" instead of others, and be required to address "contentions that its interpretation will have deleterious implications." 305

Going even further, Professor Ronald Levin has argued that while step one of Chevron review should encompass all traditional tools of statutory construction, ${ }^{306}$ step two of Chevron review should be replaced entirely with arbitrary and capricious review. ${ }^{307}$ Professor Levin characterized the second step of Chevron review as vague, ${ }^{308}$ verging on internal incoherence, ${ }^{309}$ and potentially redundant. ${ }^{310}$ Replacing step two with arbitrary and capricious review would transform the second prong from being overly deferential to being a credible step in Chevron review that ensures an agency's decision "is not only consistent with congressional intent, but also socially responsible." "311

The substitution of arbitrary and capricious review might be considered yet another step in the erosion of Chevron deference to agency decisions. Indeed, recent Supreme Court cases have whittled down the scope of agency deference. The Court in Christensen denied

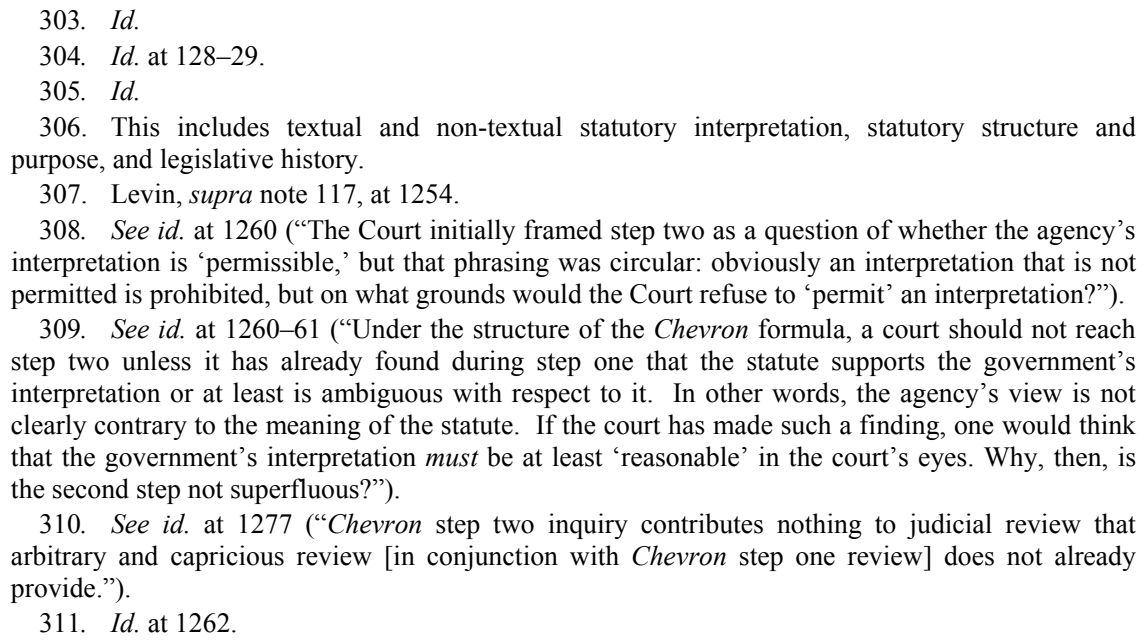

308. See id. at 1260 ("The Court initially framed step two as a question of whether the agency's interpretation is 'permissible,' but that phrasing was circular: obviously an interpretation that is not permitted is prohibited, but on what grounds would the Court refuse to 'permit' an interpretation?").

309. See id. at 1260-61 ("Under the structure of the Chevron formula, a court should not reach step two unless it has already found during step one that the statute supports the government's interpretation or at least is ambiguous with respect to it. In other words, the agency's view is not clearly contrary to the meaning of the statute. If the court has made such a finding, one would think that the government's interpretation must be at least 'reasonable' in the court's eyes. Why, then, is the second step not superfluous?").

310. See id. at 1277 ("Chevron step two inquiry contributes nothing to judicial review that arbitrary and capricious review [in conjunction with Chevron step one review] does not already provide.").

311. Id. at 1262. 
deference to a Department of Labor opinion letter that was not promulgated subject to formal rulemaking procedures. ${ }^{312}$ In Mead, a tariff classification ruling by the United States Customs Service was similarly denied deference because of the lack of formal procedures and the sheer volume of tariff classification rulings issued by the department; rulings "churned out at a rate of 10,000 a year at an agency's 46 scattered offices" simply could not have the force of law. ${ }^{313}$ This was so, despite ambiguity in the relevant administering statute, and the authoritativeness of the agency's position regarding that ambiguity. ${ }^{314}$ In FDA v. Brown \& Williamson Tobacco Corp., ${ }^{315}$ the Court denied deference to the FDA's assertion of jurisdiction over tobacco products because it involved a policy question that Congress could not have intended for the agency to address unilaterally. ${ }^{316}$ Moreover, Barnhart v. Walton suggests that Chevron deference will not always be given uniformly, but will be assessed on a case-by-case basis. ${ }^{317}$

Similarly, substitution of arbitrary and capricious review for the second prong of Chevron would deny agencies automatic deference in the face of statutory ambiguity, in an effort to require agencies to justify their decisions and encourage courts to perform nuanced and detailed reviews of the processes used to make those decisions. In the Zuni case, such a detailed look might have denied deference for an agency interpretation motivated by an arguably reasonable, if impractical in application, methodological intent. Nevertheless, the implementation of arbitrary and capricious review in the Chevron framework has significant benefits. Such an application would strengthen the overly deferential nature of the second prong, transforming it into a test which genuinely ensures that agency action is aligned with congressional intent. Moreover, it would remove the artificial distinction drawn between the legal interpretations usually associated with Chevron review, and the reasoned decision-making usually associated with arbitrary and capricious review. At the heart of arbitrary and capricious review is careful examination of an agency's reasoning process; an evaluation, therefore, of the conclusions an agency drew from its interpretation of a

312. Christensen v. Harris County, 529 U.S. 576, 587 (2000).

313. United States v. Mead Corp., 533 U.S. 218, 233 (2001).

314. Id. at 257 (Scalia, J., dissenting).

315. 529 U.S. $120(2000)$.

316. Id. at 133 .

317. 535 U.S. 212, 221-22 (2002). 
statute during its reasoning process is a necessary and integral part of arbitrary and capricious review. ${ }^{318}$

Equating step two of Chevron review with arbitrary and capricious review would also deter a court's inclination to review the decisionmaking process employed by an agency without any regard to the policy consequences of that agency's decision. The questionable policy consequences of an agency's interpretation should be among the factors a court considers when reviewing the decision-making process. ${ }^{319}$ A decision with absurd, short-sighted, or nonsensical consequences necessarily calls into question the decision-making process, and should prompt the court to require an agency explanation addressing how such a decision resulted from a supposedly rational procedure.

\section{Applying "Hard-Look" Review to Zuni}

Although Respondents framed the issue as one of simple deference to the Department of Education's choice of methodology, Zuni involved the much broader topic of public school finance and how it affects equal access to educational opportunities. Unfortunately, traditional Chevron review constrained the parties' opportunities to educate the Court on the practical effects of the Secretary's formula, thus denying the Court an opportunity to make a proper determination of permissibility at step two of Chevron review. To be sure, wrangling during oral argument and in the briefs about the definition of the word "percentile" was important in identifying the intent behind the Impact Aid program, but that determination should not have been made in isolation from a review of the practical effects of a chosen definition. Moreover, there was scant evidence that the agency used its expertise regarding the academic challenges faced by Native American schoolchildren or the methodological weaknesses inherent in the equalization formulas at issue to make a decision in the case.

Replacing the highly deferential second prong of Chevron review with the "hard-look" of arbitrary and capricious review would have required the Justices to "steep themselves in agency policy and the substantive debate framing the issue," ${ }^{20}$ and would have given the Department an opportunity to explain why its interpretation was good policy in light of the Impact Aid program's purpose. ${ }^{321}$ Professor

318. Levin, supra note 117, at 1273.

319. Id. at 1294.

320. Seidenfeld, supra note 202, at 128-29.

321. See id. at 83 . 
Levin's model provides the appropriate structure for such a change to Chevron review. At step one of Chevron review, the Court should use all tools of statutory interpretation to determine whether Congress has indeed spoken to the question at issue. In the Zuni case, tools of statutory interpretation did not yield a clear answer: the plain language did not address whether Congress intended for the Department to weight LEAs based on population when ranking those same LEAs in order of per-pupil expenditure, ${ }^{322}$ legislative history could have been interpreted both for and against the agency; and review of the statutory scheme in which Impact Aid exists was inconclusive. As a result, the case should have gone to step two of Chevron review.

Arbitrary and capricious review at step two of Chevron review would have resulted in a more nuanced and holistic review of the Secretary's interpretation, starting with a review of process. Such a review would have asked why, for instance, the Department declined to engage in formal notice-and-comment procedures when the statutory language of Impact Aid changed in the 1994 re-authorization. The Court could have also required the Department to detail the alternatives that were considered. For instance, in light of the participation of just three states in the Impact Aid program, did the agency consider making equalization determinations on a case-by-case basis so as to avoid masking un-equalized funding schemes? Alternatively, instead of insisting that its interpretation was the only way to address outliers, could the Department have instead relied on $\S 7709$ (b)(2)(B)(ii) of the statute, which directed the Secretary to consider the costs of unique school districts in its equalization determinations? Moreover, did the Department consider the potential inability of its own methodology to fail to remove district outliers?

Step two arbitrary and capricious review would have also encouraged the Court to consider the practical consequences of the Department's interpretation, and whether those consequences are in contrast to congressional intent underlying Impact Aid. What will be the effect of the Department's interpretation on educational funding for students in New Mexico? In direct contradiction to congressional intent, does the Secretary's interpretation negatively affect students impacted by a federal presence in their school district? Does the interpretation allow

322. Arguably, Congress did not have to speak to this question because it used language explicitly stating that LEAs are to be ranked based on per-pupil expenditure alone. In light, however, of the Secretary's use of weighted ranking prior to 1994, and because of the inconclusive results of legislative history and statutory construction review, a more nuanced review at step two is warranted. 
a state to mask a funding system that is not genuinely equalized? In light of evidence that the answer to the last two questions is "yes," why did the Secretary insist on using the agency's easier-to-meet equalization standard?

Finally, arbitrary and capricious "hard-look" review at step two of Chevron review would have addressed the tension regarding agency expertise. Neither submitted briefs nor oral argument in the case suggested that the agency brought expertise regarding education of Native American schoolchildren, methodological flaws inherent in restricted range ratios, or statistical infirmities in the Department's own interpretation to bear in making a decision. ${ }^{323}$ Not only would arbitrary and capricious review have allowed the Department to illustrate the extent to which its expertise informed the Secretary's interpretation, but the review would have also provided for the appropriate deference once that illustration was made. After all, arbitrary and capricious review does not allow a Court to substitute its judgment for that of the agency, but rather ensures that a decision was made based on consideration of all relevant factors required to make a decision that both falls within the agency's scope of authority, and heeds the original intent of Congress.

\section{CONCLUSION}

At one point during oral argument in the Zuni case, Justice Breyer noted, "What are, what is it we are distributing? A simple question, I guess, for a statistician. I unfortunately am not one and can't find one, so I have no idea what this statute means." ${ }^{2324}$ Although comedic, the quote illustrates that the Justices were not presented with sufficient information to properly determine at step two of Chevron review whether the Secretary's interpretation was made with the expertise that Congress intended the Department use, or whether the interpretation was in furtherance of congressional intent. To avoid this problem in the future, step two of Chevron review should be fortified with the standards of arbitrary and capricious review so that the Supreme Court itself, or a lower court on remand, can properly consider agency process, policy consequences, pursuit of congressional intent, and agency expertise when

323. The Department did not maintain specific expertise on its part but did argue that "[t]he uniform view of practitioners in the field of education finance... is that a disparity test like the one in the Impact Aid statute must take into account the number of pupils served by an LEA." Brief for the Federal Respondent, supra note 71, at 17. The Department did not elaborate, however, on whether such an application is reasonable if it eliminates twenty-five percent of LEAs in New Mexico.

324. Transcript of Oral Argument, supra note 200, at 11. 
196

[Vol. 56

reviewing an agency's statutory interpretation. In light of the impact that equalized funding has on the educational opportunities of students, such a rigorous review in the Zuni case was not only warranted, but necessary. 